\title{
Urea impairs $\beta$ cell glycolysis and insulin secretion in chronic kidney disease
}

\author{
Laetitia Koppe, ${ }^{1,2}$ Elsa Nyam, ${ }^{1,2,3}$ Kevin Vivot, ${ }^{1,2}$ Jocelyn E. Manning Fox, ${ }^{4}$ Xiao-Qing Dai, ${ }^{4}$ Bich N. Nguyen,,${ }^{5,6}$ Dominique Trudel, $, 5,5$ \\ Camille Attané, ${ }^{1,2}$ Valentine S. Moullé, ${ }^{1,2}$ Patrick E. MacDonald, ${ }^{4}$ Julien Ghislain, ${ }^{1,2}$ and Vincent Poitout ${ }^{1,2,3,7}$

\begin{abstract}
'Montreal Diabetes Research Center, Montreal, Quebec, Canada. ²entre de Recherche du Centre Hospitalier de l'Université de Montréal (CRCHUM), Montréal, Québec, Canada. ${ }^{3}$ Department of Biochemistry and Molecular Medicine, Université de Montréal, Montréal, Québec, Canada. ${ }^{4}$ Department of Pharmacology and Alberta Diabetes Institute, University of Alberta, Edmonton, Alberta, Canada. ${ }^{5}$ Department of Pathology, CHUM, Montréal, Québec, Canada. ${ }^{6}$ Department of Pathology and Cell Biology, Université de Montréal, Montréal, Québec, Canada. Department of Medicine, Université de Montréal, Montréal, Québec, Canada.
\end{abstract}

\begin{abstract}
Disorders of glucose homeostasis are common in chronic kidney disease (CKD) and are associated with increased mortality, but the mechanisms of impaired insulin secretion in this disease remain unclear. Here, we tested the hypothesis that defective insulin secretion in CKD is caused by a direct effect of urea on pancreatic $\beta$ cells. In a murine model in which CKD is induced by $5 / 6$ nephrectomy (CKD mice), we observed defects in glucose-stimulated insulin secretion in vivo and in isolated islets. Similarly, insulin secretion was impaired in normal mouse and human islets that were cultured with disease-relevant concentrations of urea and in islets from normal mice treated orally with urea for 3 weeks. In CKD mouse islets as well as ureaexposed normal islets, we observed an increase in oxidative stress and protein 0 -GIcNAcylation. Protein 0 -CIcNAcylation was also observed in pancreatic sections from CKD patients. Impairment of insulin secretion in both CKD mouse and urea-exposed islets was associated with reduced glucose utilization and activity of phosphofructokinase 1 (PFK-1), which could be reversed by inhibiting $\boldsymbol{O}$-GIcNAcylation. Inhibition of $\boldsymbol{O}$-GIcNAcylation also restored insulin secretion in both mouse models. These results suggest that insulin secretory defects associated with CKD arise from elevated circulating levels of urea that increase islet protein 0 -ClcNAcylation and impair glycolysis.
\end{abstract}

\section{Introduction}

Disorders of glucose homeostasis affect approximately $50 \%$ of patients suffering from chronic kidney disease (CKD) (1-4) and play a major role in their mortality $(5,6)$. Glucose homeostasis relies on sufficient production of insulin from pancreatic $\beta$ cells and adequate insulin action on peripheral tissues. Although several mechanisms involved in insulin resistance in CKD have been identified (7), few studies have considered the contribution of $\beta$ cell dysfunction and its underlying mechanisms.

CKD is characterized by the progressive retention of metabolites normally excreted by the kidney, collectively termed "uremic toxins," many of which have adverse effects on numerous organs $(8,9)$. The major uremic metabolite, urea, is usually considered to have negligible toxicity. Addition of urea to the dialysate following conventional dialysis is well tolerated (10), and an increase in the urea reduction rate from $66 \%$ to $75 \%$ has no impact on patient survival (11). However, the view that urea is simply an innocent bystander was recently challenged by the observation that daily dialysis (12) and hemodiafiltration (13), which improve the removal of uremic toxins including urea, improve survival in CKD patients. Furthermore, evidence for urea toxicity is beginning to emerge. Urea was shown to affect cellular functions indirectly, by modifying serum or tissue compounds, and directly through increased

Conflict of interest: The authors have declared that no conflict of interest exists. Submitted: December 22, 2015; Accepted: June 24, 2016.

Reference information: J Clin Invest. 2016;126(9):3598-3612. doi:10.1172/JCI86181. oxidative stress (14), which impairs glucose uptake in adipocytes (15), decreases tight junctions in intestinal cells (16), and induces endothelial dysfunction (17). Recently, urea was shown to induce posttranslational modifications that compromise protein function. Urea increases $O$-linked $N$-acetylglucosamine $(O$-GlcNAc) modification of insulin-signaling proteins in adipocytes and endothelial cells $(15,17)$ and increases protein carbamylation indirectly via its degradation into the reactive compound cyanate (18). Despite the expanding data on its pathophysiological effects, to our knowledge, urea has never been linked to $\beta$ cell dysfunction.

Insulin secretion is tightly regulated to maintain blood glucose levels within a narrow range. Rising blood glucose levels stimulate insulin secretion from $\beta$ cells. This involves $\beta$ cell glucose transporters that equilibrate the extracellular and intracellular glucose concentrations (19). Glucose metabolism, the key signal for insulin secretion, is controlled by the glycolytic enzyme glucokinase (GK), generating glucose-6-phosphate (G6P), and by phosphofructokinase 1 (PFK-1), which converts fructose 6-phosphate to fructose 1,6-bisphosphate. Subsequent glucose metabolism leads to an increase in the ATP/ADP ratio, which induces closure of ATP-sensitive potassium channels $\left(\mathrm{K}^{+}{ }_{\text {ATP }}\right.$ channels), resulting in membrane depolarization, opening of voltage-gated calcium channels, and $\mathrm{Ca}^{2+}$ influx. The resulting increase in $\left[\mathrm{Ca}^{2+}\right]$ triggers fusion and exocytosis of insulin-containing granules.

Oxidative stress is common in CKD patients, and reduction of oxidative stress has a number of beneficial effects $(20,21)$. In the $\beta$ cell, ROS act as second messengers in glucose-stimulated insulin 
Table 1. Biometry, organ weights, and metabolic parameters in sham and CKD mice 3 weeks after surgery

\begin{tabular}{|c|c|c|c|}
\hline & Sham & CKD & $P$ value \\
\hline Mice $(n)$ & 6 & 9 & \\
\hline \multicolumn{4}{|l|}{ Biometry } \\
\hline BW, g & $23.7 \pm 0.6$ & $22.7 \pm 0.5$ & NS \\
\hline \multicolumn{4}{|l|}{ Organ weight } \\
\hline Liver, mg/10 g BW & $454.8 \pm 147.2$ & $467.7 \pm 144.5$ & NS \\
\hline Gastrocnemius, mg/10 g BW & $56.6 \pm 4.7$ & $51.4 \pm 4.5$ & NS \\
\hline Pancreas, mg/10 g BW & $108.1 \pm 3.7$ & $124.6 \pm 2.5$ & 0.001 \\
\hline eWAT, mg/10 g BW & $85.8 \pm 9.4$ & $42.7 \pm 2.5$ & $<0.001$ \\
\hline scWAT, $\mathrm{mg} / 10 \mathrm{~g}$ BW & $52.5 \pm 4.1$ & $28.0 \pm 4.0$ & 0.0019 \\
\hline rWAT, mg/10 g BW & $14.6 \pm 3.6$ & $6.9 \pm 1.9$ & NS \\
\hline \multicolumn{4}{|l|}{ Metabolic parameters } \\
\hline Urea, mmol/l & $10.1 \pm 0.6$ & $27.8 \pm 0.4$ & $<0.001$ \\
\hline Creatinine, $\mu \mathrm{mol} / \mathrm{l}$ & $8.5 \pm 1.4$ & $24.2 \pm 1.8$ & $<0.001$ \\
\hline Fed plasma insulin, ng/ml & $1.18 \pm 0.25$ & $0.73 \pm 0.11$ & NS \\
\hline Fasting plasma insulin, ng/ml & $0.92 \pm 0.05$ & $0.49 \pm 0.17$ & 0.03 \\
\hline Fed blood glucose, $\mathrm{mmol} / \mathrm{l}$ & $8.3 \pm 0.2$ & $9.9 \pm 0.4$ & $<0.001$ \\
\hline Fasting blood glucose, $\mathrm{mmol} / \mathrm{l}$ & $8.7 \pm 0.3$ & $8.8 \pm 0.2$ & NS \\
\hline Fed NEFA, mmol/l & $0.063 \pm 0.006$ & $0.101 \pm 0.015$ & 0.03 \\
\hline Fasting NEFA, mmol/l & $0.650 \pm 0.050$ & $0.846 \pm 0.081$ & NS \\
\hline
\end{tabular}

Data represent the mean \pm SEM. NEFA, nonesterified fatty acid; eWAT, epididymal white adipose tissue; rWAT, retroperitoneal WAT; scWAT, subcutaneous WAT. patients (Table 1). BW was slightly, but not significantly, lower in CKD mice, and food intake was not different between the 2 groups (Supplemental Figure 1, A and B; supplemental material available online with this article; doi:10.1172/JCI86181DS1). Fat mass was decreased in CKD mice without changes in lean mass (Table 1). Fed blood glucose levels increased in the first week after surgery and remained high for up to 3 weeks $(9.9 \pm 0.4 \mathrm{mmol} / 1$ vs. $8.3 \pm 0.2 \mathrm{mmol} / \mathrm{l}$ in sham mice, $n=12-13, P<$ 0.001; Table 1 and Supplemental Figure 1C), which was associated with hypoinsulinemia (Supplemental Figure 1D). Five-hour fasted glucose levels were similar in CKD and sham mice, however, fasting insulinemia gradually decreased to approximately $50 \%$ of sham-operated levels by 3 weeks $(0.49$ $\pm 0.17 \mathrm{ng} / \mathrm{ml}$ vs. $0.92 \pm 0.05 \mathrm{ng} / \mathrm{ml}, n=9-10$, $P<0.01$; Table 1 and Supplemental Figure 1D). Subsequent experiments on CKD and sham mice were performed at 3 weeks after surgery. Intraperitoneal glucose tolerance tests (IPGTTs) revealed glucose intolerance (Figure 1, A and B) and lower plasma insulin levels during glucose challenge (Figure 1C) in CKD mice. In hyperglycemic clamps (HGCs), CKD mice had significantly lower insulin secretion in response to glucose $(1.2 \pm 0.1 \mathrm{ng} / \mathrm{ml}$ vs. $2.2 \pm 0.4 \mathrm{ng} / \mathrm{ml}$ in sham mice, $n=7, P<0.05$; secretion (GSIS) (22), but persistent oxidative stress causes $\beta$ cell dysfunction and apoptosis (23). The extreme sensitivity of $\beta$ cells to overproduction of ROS may be explained by the cells' relatively low levels of antioxidant enzymes (24). ROS-dependent glucose metabolism through the hexosamine biosynthesis pathway (HBP) has been implicated in many of the adverse effects of chronic hyperglycemia (25). Between $1 \%$ and $3 \%$ of the glucose that enters the cell is converted by the HBP to UDP-GlcNAc, the substrate for protein $O$-GlcNAcylation, a reversible posttranslational modification that consists of the addition of carbohydrates (O-GlcNAc) on serine and threonine residues $(26,27)$. Prolonged activation of the HBP and O-GlcNAcylation impair insulin secretion (28-30).

Here, we tested the hypothesis that CKD is associated with defective insulin secretion due to the direct action of urea on $\beta$ cells to increase oxidative stress and protein O-GlcNAcylation. Specifically, we asked the following questions: 1 ) Is $\beta$ cell function impaired in a CKD mouse model, in uremic mice, and in urea-treated islets ex vivo? 2) What are the roles of ROS and $O$-GlcNAcylation in the insulin secretory defect? and 3) What are the targets of ROS and O-GlcNAcylation in the stimulus-secretion coupling pathway?

\section{Results}

CKD is associated with defective insulin secretion in mice. To determine whether CKD is associated with impaired insulin secretion, we first examined $\beta$ cell function in a CKD mouse model generated by $5 / 6$ nephrectomy performed in 2 surgical steps (31) and compared function with that in sham-operated controls. Three weeks after the second surgery, circulating urea and creatinine levels were in the same range as those observed in moderate CKD
Figure 1, D-F) and a trend toward reduced insulin response to arginine (Figure 1, D, E, and G). Although C-peptide levels are frequently used to assess endogenous $\beta$ cell secretion, comparison of circulating C-peptide levels between CKD and sham mice is not informative, as the kidney is the major site of C-peptide clearance (32). Consistent with renal dysfunction, C-peptide levels during the HCG were increased in CKD mice (Figure 1H). The glucose infusion rate (GIR) (Figure 1I) and M/I index of insulin sensitivity (Supplemental Figure 1E) during the clamp were not significantly different between CKD and sham mice, suggesting no major defect in insulin sensitivity. Nevertheless, the plasma glucose disappearance rate (kITT) derived from the insulin tolerance tests (ITTs) (33) revealed a slight decrease in insulin sensitivity in CKD mice $(8.4 \% \pm 0.4 \% / \mathrm{min}$ vs. $9.9 \% \pm 0.3 \% / \mathrm{min}$ in sham mice, $n=6-8, P<0.05$; Figure $1, \mathrm{~J}$ and $\mathrm{K})$, as observed in different $\mathrm{CKD}$ models and patients (7). $\beta$ Cell mass was unaffected in CKD mice (Supplemental Figure 2, A and B). Taken together, these data suggest that CKD causes glucose intolerance at least in part because of impaired insulin secretion.

Insulin secretion is compromised in CKD mouse islets ex vivo. To confirm that the reduced insulin secretory response observed in CKD mice is due to $\beta$ cell dysfunction, islets were isolated from CKD mice, and insulin secretion was measured in 1-hour static incubations. Three weeks after surgery, insulin secretion from CKD mouse islets was reduced in response to $16.8 \mathrm{mmol} / \mathrm{l} \mathrm{glu}-$ cose $(2.9 \% \pm 0.4 \%$ vs. $4.9 \% \pm 0.7 \%$ content in sham mice, $n=5-7$, $P<0.05)$ or $35 \mathrm{mmol} / 1 \mathrm{KCl}(1.9 \% \pm 0.2 \%$ vs. $4.0 \% \pm 0.7 \%$ content in sham mice, $n=5-6, P<0.05$ ) (Figure 2, A and B), without changes in insulin content (Figure 2C), protein content (Supplemental Figure 2C), or in the levels of the transcription factor pan- 
A
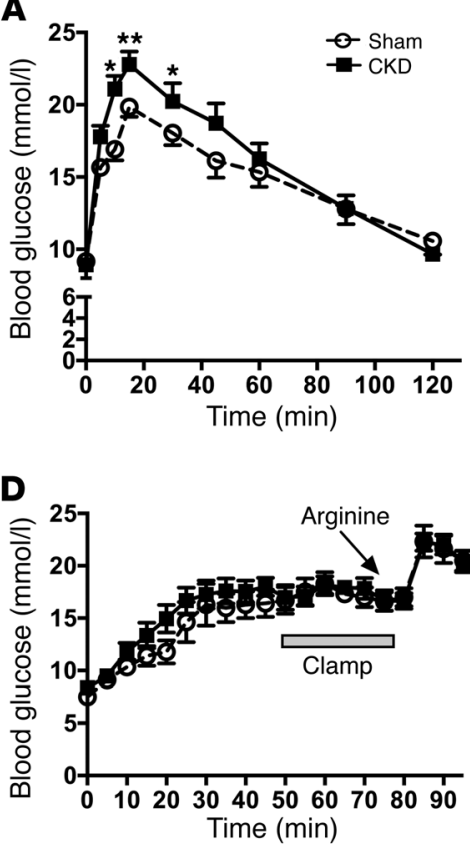

G

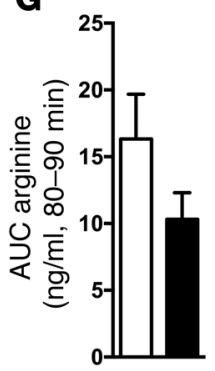

B

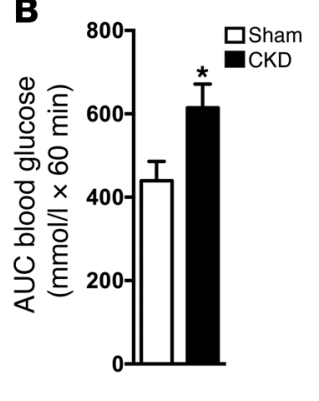

C

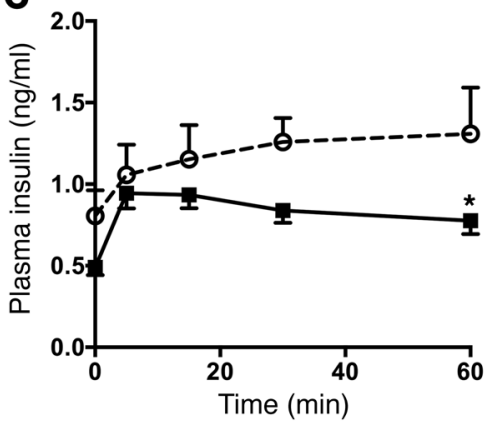

E

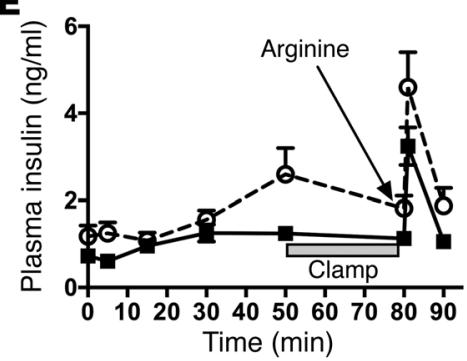

$\mathbf{F}$

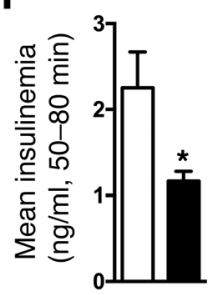

I

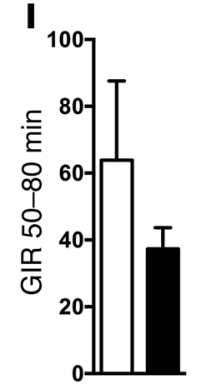

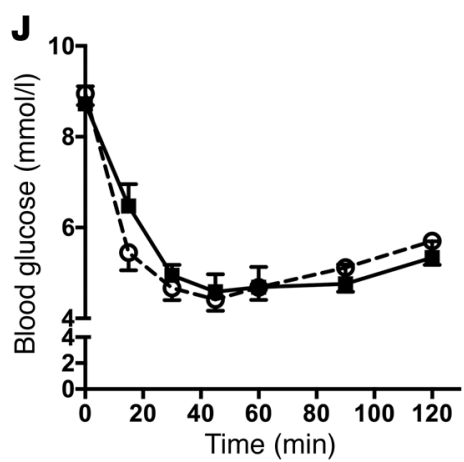

$\mathbf{K}$

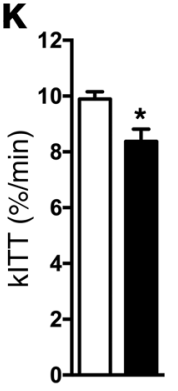

Figure 1. CKD mice have defective glucose-stimulated insulin secretion in vivo. (A) Blood glucose and (B) AUC during an IPGTT (1 g/kg) in CKD or sham-operated mice. (C) Insulin levels during the IPGTT ( $n=9-10)$. (D) Glucose levels during HGCs. (E) Insulin levels during HGCs and in response to an arginine bolus (1 mM/kg). (F) Mean insulin levels during the clamp (50-80 min). (C) Arginine-induced insulin secretion (AUC) from 80 to 90 minutes $(n=7)$. (H) Mean C-peptide during the clamp (50-80 min). (I) GIR during the clamp (50-80 min). Blood glucose (J) and kITT (K) during the IPITT (0.5 IU/kg) $(n=6-8)$. Data represent the mean \pm SEM. ${ }^{*} P<0.05$ and ${ }^{* *} P<0.01$ versus CKD for the same times; 2-way ANOVA with Bonferroni's post-hoc test for $\mathbf{A}$, C, $\mathbf{D}, \mathbf{E}$, and $\mathbf{J}$ and Student's $t$ test for $\mathbf{B}, \mathbf{F}-\mathbf{I}$, and $\mathbf{K}$.

creatic and duodenal homeobox 1 (PDX-1) (Supplemental Figure 2D). Six weeks after surgery, the decrease in insulin secretion in response to glucose was maintained, and insulin content was also reduced (Supplemental Figure 3, A and B). These data indicate that a cell-autonomous defect in insulin secretion appears in CKD mouse islets prior to any significant decrease in intracellular insulin stores. To examine the dynamics of insulin secretion, we performed perifusion experiments using islets from CKD and sham mice. As shown in Figure 2D, islets from CKD mice displayed a clear defect in first-phase insulin secretion.

Increased oxidative stress and protein O-GlcNAcylation in CKD mouse and human islets. To explore the underlying mechanisms, we examined whether ROS and protein $O$-GlcNAcylation were increased in islets from CKD mice. ROS-dependent formation of the RNA damage biomarker 8-hydroxyguanosine (8-OHG), used to evaluate oxidative stress $(34,35)$, was assessed by IHC in pancreatic sections. Whereas islets from sham-operated mice were only weakly stained compared with the adjacent exocrine tissue, CKD islets showed stronger 8-OHG staining, indicative of oxidative stress $(+50 \% \pm 4 \%$ vs. sham mice, $n=3-4, P<0.001$; Figure 3, A and B). To investigate the contribution of ROS to $\beta$ cell dysfunction, CKD mice were treated with the antioxidant $\mathrm{N}$-acetylcysteine (NAC), and insulin secretion was measured in isolated islets. NAC completely restored insulin secretion to control levels (Figure 3C), without affecting insulin content (Supplemental Figure 4A). Furthermore, NAC treatment of CKD mice restored fed glucose and insulin levels (Supplemental Table 1 and Supplemental Figure 4B). The improvement of insulin secretion was not due to a reduction in plasma urea levels during NAC treatment (Supplemental Table 1). Protein O-GlcNAcylation was then assessed in CKD islets by Western blotting and immunohistochemical analysis of pancreatic sections. O-GlcNAcylation of 
A

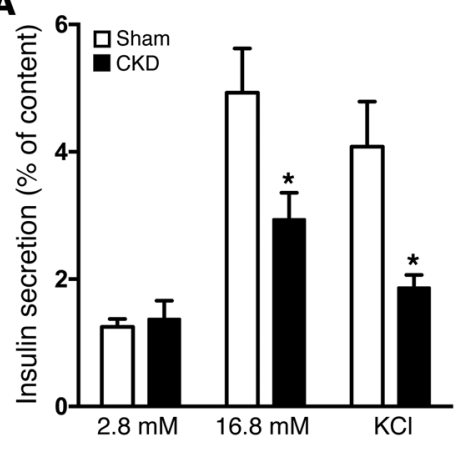

B

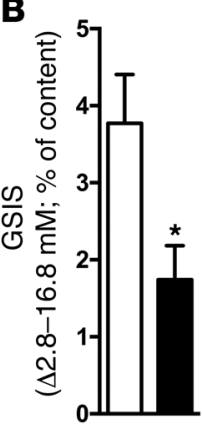

C

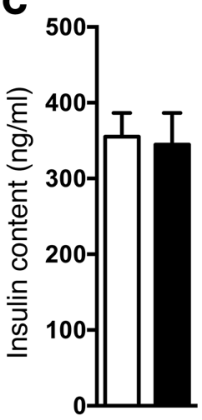

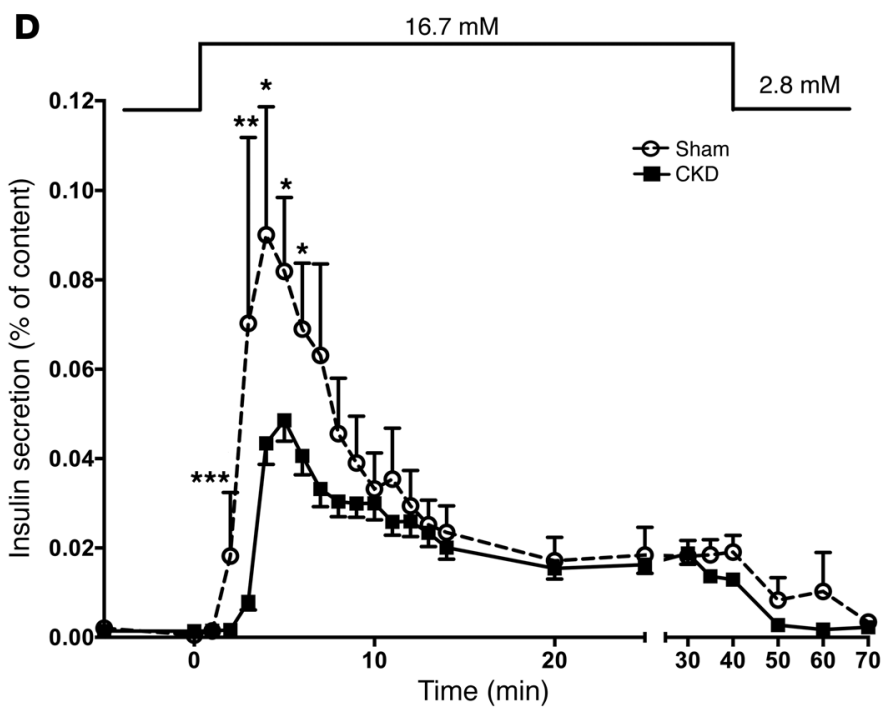

proteins was increased in islets from CKD mice $(+44 \% \pm 27 \%$ vs. sham mice, $n=3, P<0.05$; Figure 3, D, F and G). Importantly, a strong signal for protein $O$-GlcNAcylation was also observed in pancreatic sections from nondiabetic CKD patients (Supplemental Table 2) as compared with that detected in control subjects (2.08 \pm 0.53 -fold increase vs. controls, $n=3$ in each group, 4-6 islets per individual; Figure $3 \mathrm{E}$ ). Interestingly, treatment of CKD mice with NAC prevented the increase in islet protein $O-G l c N A c-$ ylation, indicating that oxidative stress is upstream of $O$-GlcNAcylation in this context (Figure 3, $\mathrm{H}$ and I). To determine whether $O$-GlcNAcylation in CKD affects $\beta$ cell function, we inhibited the HBP with the glutamine analog 6-diazo-5-oxo-L-norleucine (DON), an inhibitor of L-glutamine D-fructose 6-phosphate aminotransferase (GFAT), the rate-limiting enzyme that metabolizes fructose-6-phosphate to glucosamine-6-phosphate (36). As expected, treatment of CKD mice with DON restored islet protein $O$-GlcNAcylation to control levels (data not shown). DON treatment restored insulin secretion in CKD islets ex vivo (Figure 3J), without affecting insulin content (Supplemental Figure 4C), and normalized fed glucose levels in CKD mice (Supplemental Table 3 and Supplemental Figure 4D). Taken together, these data suggest that oxidative stress impairs insulin secretion in CKD by increasing the flux through the HBP and, consequently, O-GlcNAcylation of the islet proteins involved in insulin secretion, leading to altered glucose metabolism and/or a defect at a late step in the stimulus-secretion coupling pathway.

Figure 2. Isolated islets from CKD mice have reduced insulin release in response to glucose and $\mathrm{KCl}$. (A) Insulin secretion, shown as the percentage of insulin content, was assessed in 1-hour static incubations in islets isolated from CKD and sham mice after 3 weeks in response to 2.8 or 16.8 $\mathrm{mmol} / \mathrm{l}$ (mM) glucose or $2.8 \mathrm{mmol} / \mathrm{I}$ glucose plus $35 \mathrm{mmol} / \mathrm{l}$ $\mathrm{KCl}$. (B) CSIS ( $\Delta 2.8-16.8 \mathrm{mmol} / \mathrm{l})$ in sham and CKD mice after 3 weeks. (C) Total islet insulin content. (D) Insulin secretion in response to $2.8 \mathrm{mmol} / \mathrm{I}$ glucose from -5 to 0 minutes, 16.7 $\mathrm{mmol} / \mathrm{l}$ glucose from 0 to 40 minutes, and $2.8 \mathrm{mmol} / \mathrm{l} \mathrm{glu-}$ cose from 40 to 70 minutes in perifusion experiments. Data represent the mean \pm SEM of 5 to 10 replicate experiments. ${ }^{*} P<0.05$, ${ }^{* *} P<0.01$, and ${ }^{* *} P<0.001$ versus CKD for the same incubation condition; 1-way ANOVA with Bonferroni's post-hoc test for $\mathbf{A}$; Student's $t$ test for $\mathbf{B}$ and $\mathbf{C}$; and 2-way ANOVA with Bonferroni's post-hoc test for $\mathbf{D}$.

Chronic administration of urea impairs glucose tolerance and insulin secretion in mice. To determine whether $\beta$ cell dysfunction in CKD mice is due to chronic hyperuremia, we supplemented the drinking water with $25 \mathrm{~g} / \mathrm{l}$ urea to raise plasma urea concentrations in normal mice. Circulating urea levels were increased after 1 week and remained elevated after 3 weeks (Figure 4A). Urea-treated mice gained less weight, although food intake was not different (Supplemental Figure 5, A and B). Fed blood glucose levels were higher $(10 \pm 0.1 \mathrm{mmol} / \mathrm{l}$ vs. $9.1 \pm 0.2 \mathrm{mmol} / \mathrm{l}$ in control mice, $n=4-5, P<0.05)$, and fed insulin levels were lower $(0.6 \pm 0.1 \mathrm{ng} / \mathrm{ml}$ vs. $1.2 \pm 1 \mathrm{ng} / \mathrm{ml}$ in control mice, $n=3-4, P<0.05)$ in urea-treated mice compared with levels in controls after 1 week (Supplemental Table 4 and Supplemental Figure 5, C and D). IPGTTs performed after 3 weeks of urea administration revealed a nonsignificant trend toward glucose intolerance (Figure 4, B and D). Insulin levels during the glucose challenge were, however, significantly lower in urea-treated mice $(0.7 \pm 0.1 \mathrm{ng} / \mathrm{ml}$ vs. $1.6 \pm 0.3 \mathrm{ng} /$ $\mathrm{ml}$ in controls at $15 \mathrm{~min}, n=3-4, P<0.05$; Figure $4 \mathrm{C}$ ), suggestive of an insulin secretory defect. Consistent with this, islets isolated after 3 weeks of urea administration secreted significantly less insulin in response to $16.8 \mathrm{mmol} / \mathrm{l}$ glucose $(4.8 \% \pm 0.9 \%$ vs. $7.2 \%$ $\pm 1.4 \%$ content in controls, $n=6-7, P<0.05)$ or $35 \mathrm{mmol} / \mathrm{l} \mathrm{KCl}$ $(2.3 \% \pm 0.3 \%$ vs. $3.7 \% \pm 0.6 \%$ content in control mice, $n=4-5)$ (Figure 4, E and F), whereas insulin content was not affected (Supplemental Figure 5E). Protein O-GlcNAcylation was increased in islets from urea-treated mice $(+55 \% \pm 1 \%$ vs. controls, $n=3-4$, $P<0.05$; Figure $4, \mathrm{G}$ and $\mathrm{H}$ ). Thus, administration of urea mimics the insulin secretory defect observed in CKD mice.

Urea impairs insulin secretion by increasing ROS production and protein O-GlcNAcylation in islets. To rule out the possibility that the insulin secretory defect observed in CKD and urea-fed mouse islets is indirectly due to hyperglycemia or weight loss, we exposed normal mouse islets to increasing concentrations of urea for 24 hours. Exposure to $10 \mathrm{mmol} / \mathrm{l}$ urea, comparable to levels in sham mice and healthy patients, was inconsequential. In contrast, exposure to concentrations of urea of $20 \mathrm{mmol} / \mathrm{l}$ or greater, comparable to levels in CKD mice and humans, inhibited GSIS relative to the osmotic control mannitol (Figure 5A). Insulin content was not 
A
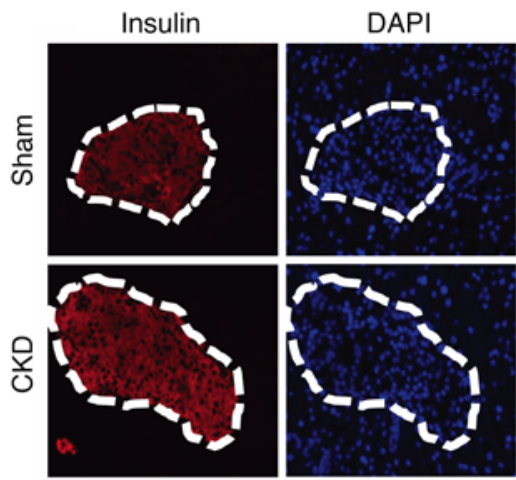

D
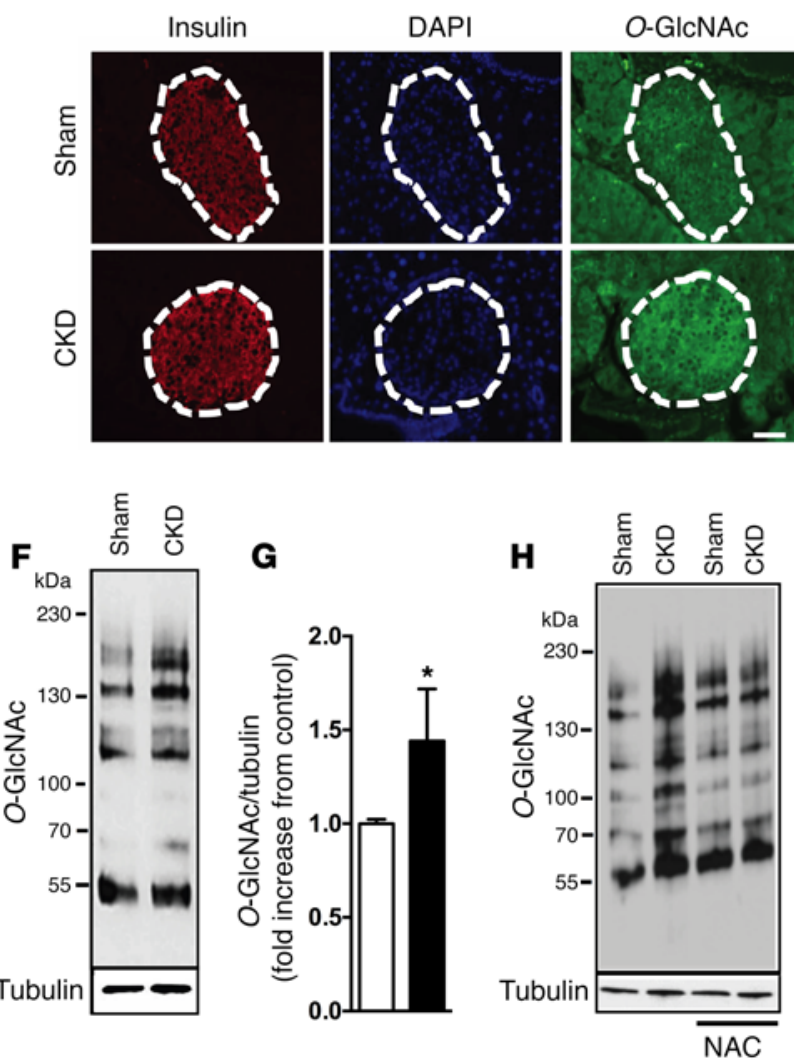

B

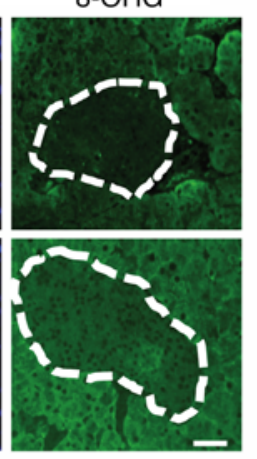

O-GICNAC
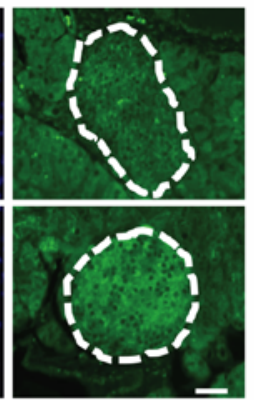
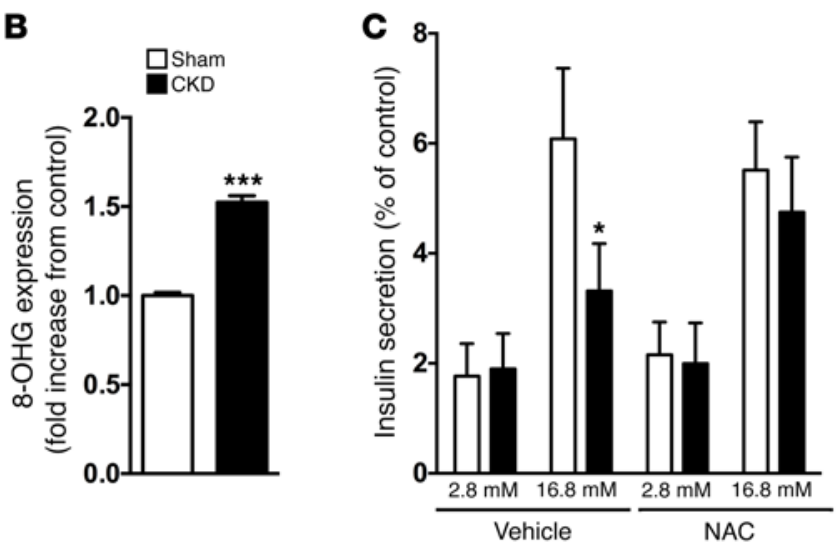

E

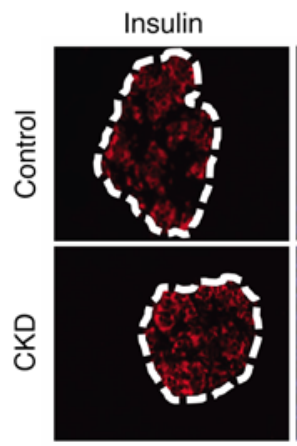

Human pancreas

$$
\text { DAPI }
$$
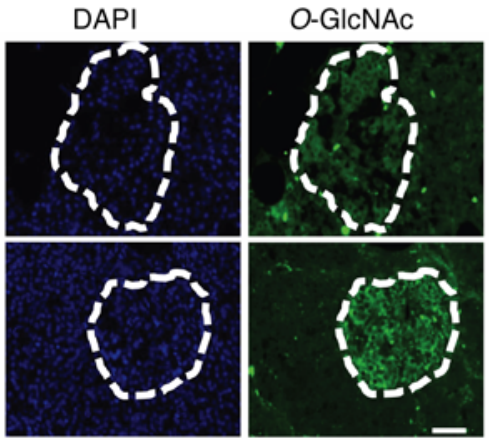

I

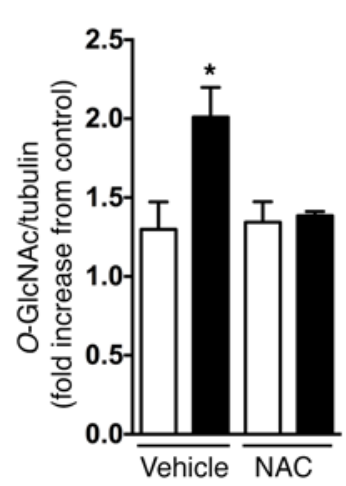

J

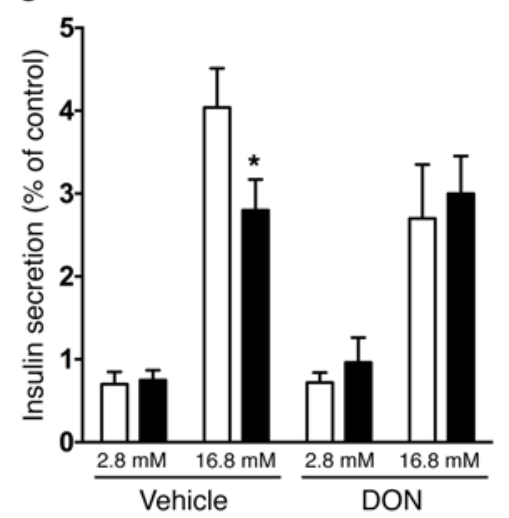

Figure 3. CKD mice show an increase of $\mathbf{O}$-GIcNAcylation in islets and oxidative stress markers. (A and B) Immunostaining of 8-OHG in pancreatic sections of CKD and from sham-operated mice and quantification. (C) Insulin secretion, shown as the percentage of insulin content, was assessed in 1-hour static incubations in isolated islets from CKD or sham-operated mice in response to 2.8 or $16.8 \mathrm{mmol} / \mathrm{I}(\mathrm{mM})$ glucose after 3 weeks, with or without NAC treatment (200 mg/kg/day p.o., $n=6-7)$. ( $\mathbf{D}$ and $\mathbf{E})$ Immunostaining of $O$-GIcNAcylation (O-GlcNAc) in pancreatic sections from CKD and sham-operated mice $(\mathbf{D})$ and from control and CKD patients $(\mathbf{E})$. (F and $\mathbf{G})$ Representative Western blot and quantification $(n=3)$ for total islet protein 0 -CIcNAcylation. (H and I) Representative Western blot and quantification $(n=4)$ for total protein 0 -GIcNAcylation in isolated islets from CKD and sham mice with or without NAC treatment. (J) Insulin secretion, shown as the percentage of insulin content in response to 2.8 or $16.8 \mathrm{mmol} / \mathrm{I} \mathrm{glucose,} \mathrm{in} \mathrm{isolated} \mathrm{islets} \mathrm{from} \mathrm{CKD} \mathrm{mice}$ treated with or without DON $(1.5 \mathrm{mg} / \mathrm{kg} 3$ times/week, $n=5-8)$. Data represent the mean \pm SEM. ${ }^{*} P<0.05$ and ${ }^{* *} P<0.001$ versus CKD for the same incubation condition; Student's $t$ test for B and $\mathbf{D}$ and 1-way ANOVA with Bonferroni's post-hoc test for C, I, and J. Scale bars: $50 \mu \mathrm{m}$.

affected in the presence of $20 \mathrm{mmol} / \mathrm{l}$ urea, but decreased at higher concentrations (Supplemental Figure 6A). To specifically examine insulin secretion without the confounding effects of reduced insulin or protein content (Supplemental Figure 6, A and B), subsequent experiments were performed with $20 \mathrm{mmol} / \mathrm{l}$ urea. Urea treatment of islets resulted in a 1.5-fold increase in ROS $(n=8$,
$P<0.05$; Figure 5B), whereas, in the presence of NAC, levels of ROS and GSIS were restored to control levels (Figure 5, B and C). Urea treatment also increased protein $O$-GlcNAcylation in isolated islets $(+75 \% \pm 37 \%$ vs. controls, $n=4, P<0.05$; Figure 5 , D and E) and in MIN6 cells ( $+59 \% \pm 14 \%$ vs. controls, $n=3, P<0.05$; Supplemental Figure 7, A and B). Urea-induced protein $O$-GlcNAcyla- 
A

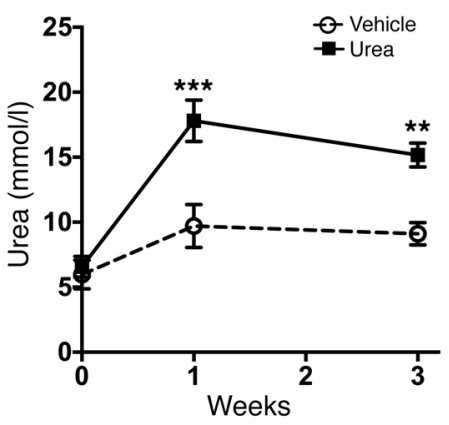

B

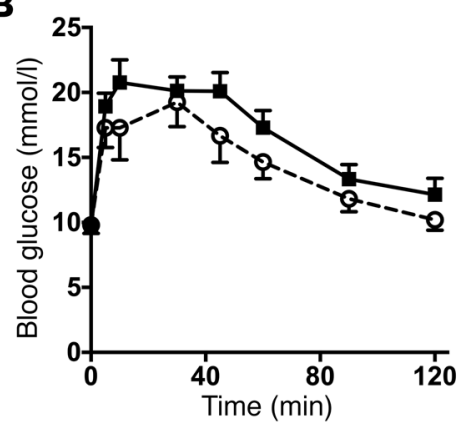

$\mathbf{F}$

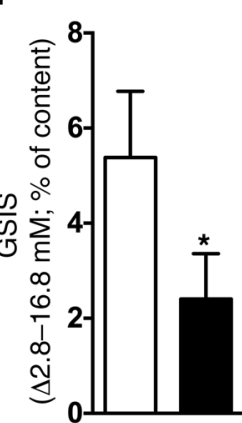

C

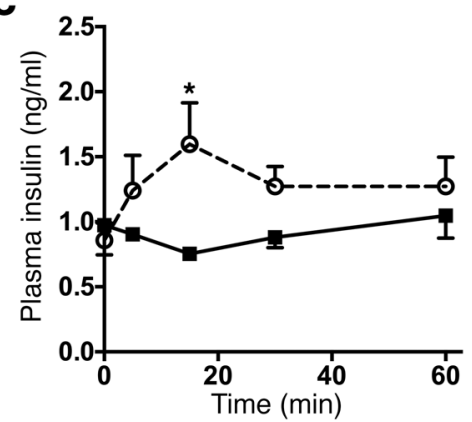

G

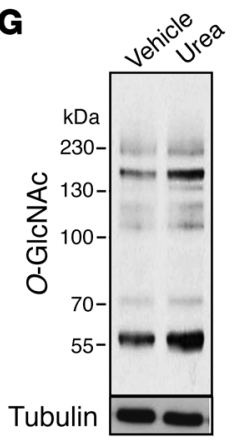

H

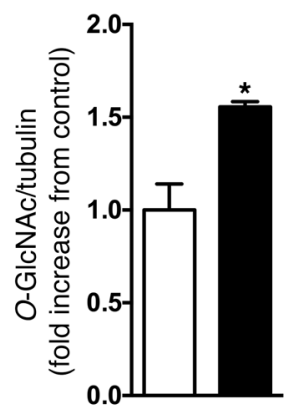

Figure 4. Exposure to urea in drinking water increases circulating urea levels and inhibits insulin secretion. (A) Urea consumption in drinking water $(25 \mathrm{~g} / \mathrm{l})$ elevates blood urea levels independently of renal failure $(n=4-5)$. (B) Blood glucose and (C) corresponding insulin levels during IPGTTs ( $n=3-4)$. (D) AUC during IPGTTs. (E) Insulin secretion shown as the percentage of insulin content assessed in 1-hour static incubations in response to 2.8 or 16.8 $\mathrm{mmol} / \mathrm{l}(\mathrm{mM})$ glucose or $2.8 \mathrm{mmol} / \mathrm{l}$ glucose plus $35 \mathrm{mmol} / / \mathrm{KCl}$ in islets from mice after 3 weeks with or without urea in drinking water ( $n=5-7)$. (F) GSIS $(\Delta 2.8-16.8 \mathrm{mM})(n=5-7)$. (G) Representative Western blot and $(\mathbf{H})$ quantification for total protein 0 -GIcNAcylation in islets in mice with or without addition of urea to the drinking water for 3 weeks $(n=3-4)$. Data represent the mean $\pm \mathrm{SEM}$. ${ }^{*} P<0.05$, ${ }^{* *} P<0.01$, and ${ }^{* * *} P<0.001$ versus vehicle; 2 -way ANOVA with Bonferroni's post-hoc test for A-C; 1-way ANOVA with Bonferroni's post-hoc test for E; and Student's $t$ test for $\mathbf{D}$, F, and $\mathbf{H}$.

tion in islets was prevented by NAC (Figure 5, D and E), confirming the relationship between ROS and $O$-GlcNAcylation observed in CKD islets. Inhibition of the HBP by DON or azaserine (AZA) restored insulin secretion (Figure $5 \mathrm{C}$ ). Consistent with this pharmacological approach, siRNA-mediated knockdown of GFAT (Supplemental Figure 7C) prevented the loss of insulin secretion in the presence of urea (Supplemental Figure 7D). Similar to mouse islets, the insulin secretory response to glucose of normal human islets (donor information in Supplemental Table 5) treated with 20 $\mathrm{mmol} / \mathrm{l}$ urea for 24 hours was strongly reduced $(8.2 \% \pm 1.7 \%$ vs. $15.8 \% \pm 2.1 \%$ in control islets, $n=5, P<0.01$ ), whereas insulin content was not affected (Figure 5, F and G). Furthermore, urea treatment increased protein $O$-GlcNAcylation of human islets $(+81 \% \pm$ $26 \%$ vs. controls, $n=5, P<0.05$; Figure $5, \mathrm{H}$ and I). Taken together, these data indicate that urea impairs GSIS by increasing ROS and protein $O$-GlcNAcylation in both rodent and human islets.

Urea is in equilibrium with the electrophilic species cyanate, which can alter protein function by reacting with the amino group of lysine residues, resulting in the generation of $\varepsilon$-aminocarbomyl-lysine (37). Under physiological conditions, $0.8 \%$ of the molar concentration of urea is converted to cyanate. To determine whether urea affects the $\beta$ cell via cyanate, mouse islets were exposed for 24 hours to concentrations of cyanate ( 0.2 and $1 \mathrm{mmol} / \mathrm{l}$ ) corresponding to $20 \mathrm{mmol} / \mathrm{l}$ urea and concentrations observed in CKD patients, respectively $(18,37)$. Cyanate dose-dependently decreased GSIS without affecting insulin content, and addition of the antioxidant NAC restored insulin secretion (Figure 6, A and C). However, in contrast to urea, cyanate did not induce an increase in protein $O$-GlcNAcylation (data not shown), nor was impaired GSIS restored by addition of DON (Figure 6C). These data suggest that the increase of $O$-GlcNAcylation and consequential decrease in insulin secretion in CKD and urea-treated islets is directly attributable to urea rather than to its degradation product cyanate.

Increased protein O-GlcNAcylation alters glucose metabolism in CKD and urea-treated islets. To identify which step of the stimulus-secretion coupling pathway is defective in CKD and urea-treated islets, we assessed glucose metabolism, mitochondrial function, and insulin exocytosis. In both urea-treated islets and islets from CKD mice, we observed a reduction in glucose utilization $(-63.3 \% \pm 8.2 \%$ and $-57.9 \% \pm 7.8 \%$ vs. their respective controls, $n=3-4, P<0.001$; Figure $7, \mathrm{~A}$ and $\mathrm{D})$, glucose oxidation $(-54.2 \%$ $\pm 8.2 \%$ and $-46.1 \% \pm 11.1 \%$ vs. their respective controls, $n=3-4$, $P<0.001$; Figure 7, B and E), and ATP production $(-60.6 \% \pm 7.8 \%$ and $-56.7 \% \pm 8.6 \%$ vs. their respective controls, $n=4, P<0.05$; Figure 7, C and F). Depolarization-induced exocytosis under basal $(2.8 \mathrm{mmol} / \mathrm{l})$ glucose conditions was unaffected by urea treatment in mouse islets (Figure $7 \mathrm{G}$ ), whereas the ability of stimulatory (16.7 $\mathrm{mmol} / \mathrm{l})$ glucose to amplify the exocytotic response was impaired ( $-60.4 \% \pm 6.2 \%$ vs. controls, $n=21-27$ cells, $P<0.001$; Figure $7 G)$. These results indicate a reduction in glycolytic flux in CKD and urea-treated islets. 
A

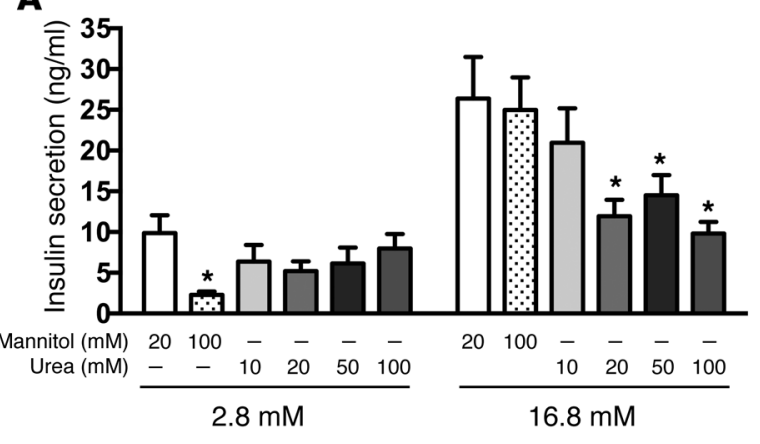

C

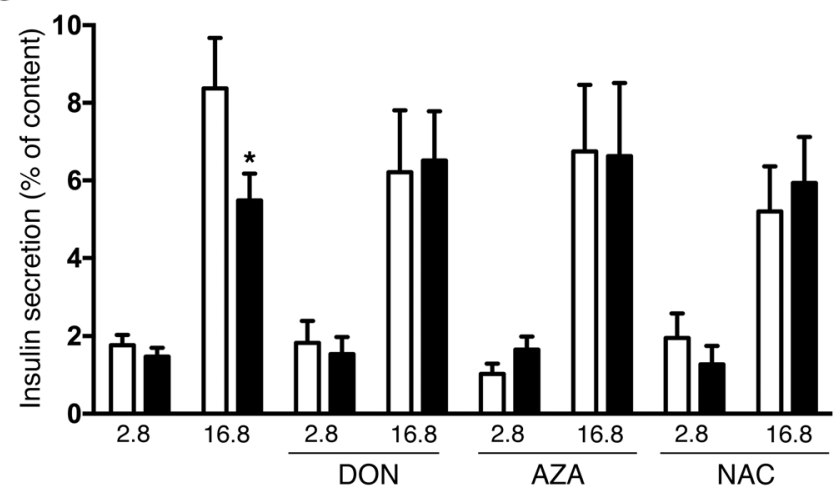

$\mathbf{F}$

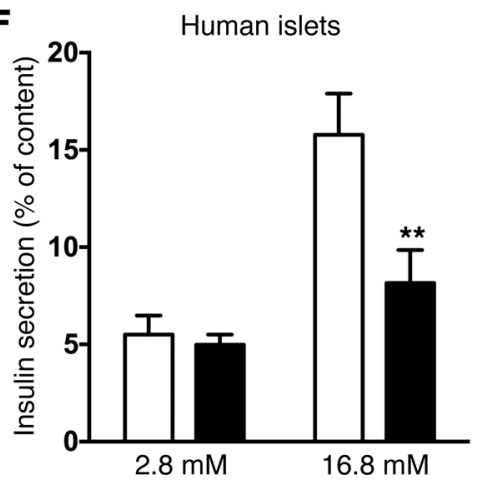

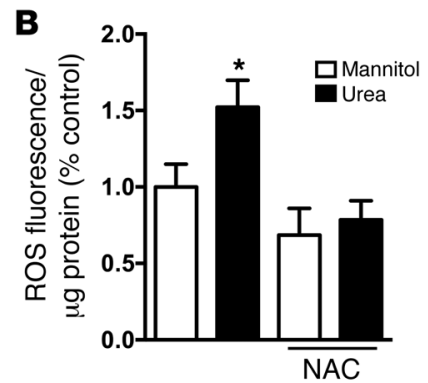

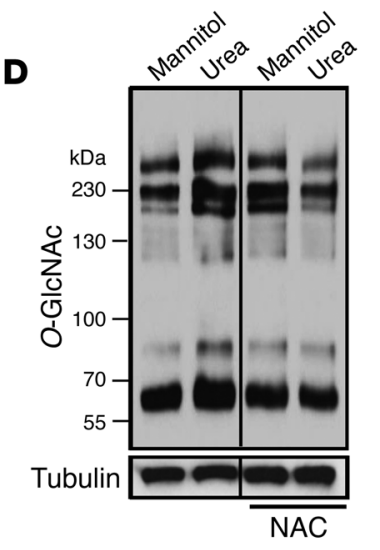

E

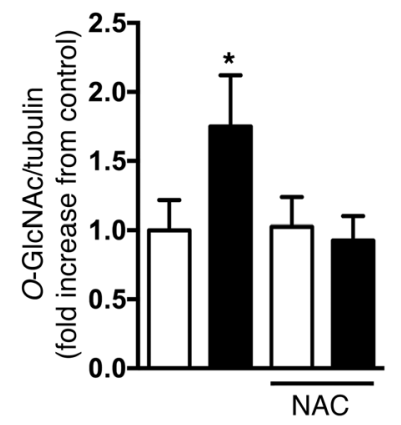

I

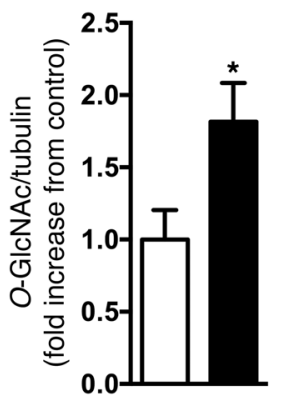

Figure 5. The insulin secretory defect resulting from exposure of normal mouse or human islets to urea is prevented by antioxidant treatment or GFAT inhibition. (A) One-hour static insulin incubations of isolated islets from normal mice cultured for 24 hours with increasing urea levels ( $n=3-5)$. (B) ROS accumulation in mouse islets treated with mannitol or urea, with or without NAC (500 $\mu \mathrm{mol} / \mathrm{I})$, for 24 hours $(n=3-8)$. (C) Insulin secretion shown as the percentage of insulin content as assessed in 1-hour static incubations in the presence of $20 \mathrm{mmol} / \mathrm{l}(\mathrm{mM})$ urea or mannitol as an osmotic control, with or without DON (20 $\mu \mathrm{mol} / \mathrm{l})$, AZA $(5 \mu \mathrm{mol} / \mathrm{I})$, or NAC $(500 \mu \mathrm{mol} / \mathrm{I})(n=4-15)$. (D) Representative Western blot and (E) quantification for total protein 0-ClcNAcylation in urea-treated islets with or without NAC $(n=4)$. (F) Insulin secretion shown as the percentage of insulin content from human islets incubated for 24 hours with $20 \mathrm{mmol} / \mathrm{l}$ urea or mannitol $(n=5)$. (C) Total insulin content in urea-treated human islets. (H) Representative Western blot and $(\mathbf{I})$ quantification for total protein 0 -GIcNAcylation in urea-treated human islets $(n=5)$. Data represent the mean \pm SEM. ${ }^{*} P<0.05$ and ${ }^{* *} P<0.01$ versus mannitol for the same incubation condition; 1-way ANOVA with Bonferroni's post-hoc test for $\mathbf{A}-\mathbf{C}, \mathbf{E}$, and $\mathbf{F}$ and Student's $t$ test for $\mathbf{G}$ and $\mathbf{~}$.

We then measured the activity of rate-limiting glycolytic enzymes upstream of enolase. Whereas GK activity was unaffected (Supplemental Figure 8, A and B), PFK-1 activity was significantly reduced in urea-treated and CKD mouse islets $(-29 \%$ $\pm 9.9 \%$ and $-28 \% \pm 8.8 \%$ vs. their respective controls, $n=3-5$, $P<0.05$; Figure 8, A and B), without changes in PFK-1 protein expression (Supplemental Figure 8, C and D). In urea-exposed MIN6 cells, we observed a marked increase in O-GlcNAcylation of PFK-1 (Figure 8C). Since PFK-1 activity can be inhibited by
O-GlcNAcylation (38), we asked whether blocking O-GlcNAcylation restores PFK-1 activity in urea-treated islets. Indeed, addition of DON prevented the inhibitory effect of urea on PFK-1 activity (Figure 8D). Addition of DON restored glucose utilization and oxidation in islets exposed to urea (Figure 8, E and F). Overall, our data suggest that chronic accumulation of urea in CKD leads to an increase in islet protein $O$-GlcNAcylation, which inhibits PFK-1 activity, reduces glucose flux, and consequently impairs insulin secretion. 
A

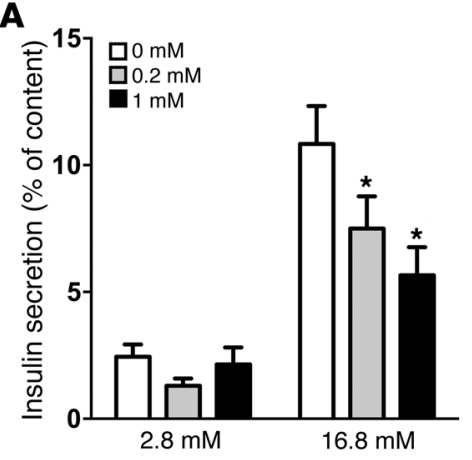

B

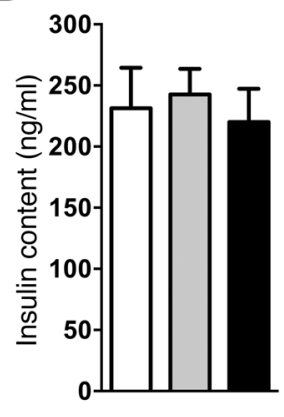

\section{C}

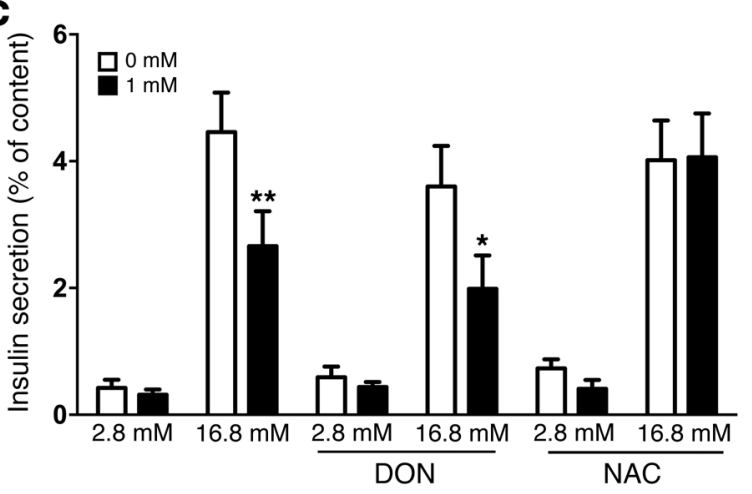

Figure 6. Cyanate inhibits insulin secretion in islets ex vivo. (A) Insulin secretion shown as the percentage of insulin content as assessed in 1-hour static incubations and (B) total islet insulin levels in the presence of $0,0.2$, or $1 \mathrm{mmol} / \mathrm{I}(\mathrm{mM})$ cyanate $(n=6)$. (C) Insulin secretion shown as the percentage of insulin content as assessed in 1-hour static incubations in the presence of $1 \mathrm{mmol} / \mathrm{l}$ cyanate with or without DON $(20 \mu \mathrm{mol} / \mathrm{l})$ or NAC $(500 \mu \mathrm{mol} / \mathrm{I})(n=5-6)$. Data represent the mean \pm SEM. ${ }^{*} P<0.05$ and ${ }^{* *} P<0.01$ versus control for the same incubation condition; 1 -way ANOVA with Bonferroni's post-hoc test.

\section{Discussion}

This study aimed to determine whether defective insulin secretion contributes to impaired glucose homeostasis in CKD and whether chronic accumulation of urea, a major uremic toxin, is the underlying cause of $\beta$ cell dysfunction in CKD. Glucose tolerance tests (GTTs), HGCs, and ex vivo islet studies in a CKD mouse model revealed impaired insulin secretion as early as 3 weeks after surgery (Figure 1 and Figure 2), whereas insulin content and $\beta$ cell mass were unaffected. Mechanistically, increased oxidative stress and protein $O$-GlcNAcylation in islets were shown to underlie the insulin secretory defect (Figure 3). Administration of urea in mice compromised insulin secretion and increased protein $O$-GlcNAcylation in islets, mimicking islet dysfunction in CKD (Figure 4). Exposure of mouse and human islets to urea impaired insulin secretion and similarly involved an increase in oxidative stress and protein $O$-GlcNAcylation (Figure 5). Increased protein $O$-GlcNAcylation in both CKD and urea-treated islets impaired GSIS by inhibiting PFK-1 activity and hence glycolysis, and urea exposure of MIN6 cells led to O-GlcNAcylation of PFK-1 (Figure 7 and Figure 8). Overall, we conclude that elevated levels of circulating urea in CKD alter glucose homeostasis by increasing ROS and protein $O$-GlcNAcylation in islets, inhibiting glycolysis and, consequently, insulin secretion.
The observed defect in insulin secretion in a CKD mouse model supports the notion that $\beta$ cell dysfunction is an important contributing factor to the perturbation of glucose homeostasis in CKD. Of note, it is likely that circulating insulin levels measured in CKD mice overestimate the endogenous secretion rate, since the kidney is responsible for approximately $30 \%$ of insulin clearance (39). Likewise, the uremic environment is associated with inhibition of the insulin degradation system in peripheral tissues (40). Insulin resistance in uremic patients was demonstrated by deFronzo et al. (41) and is widely accepted as an underlying cause of altered glucose homeostasis in CKD (4). However, type 2 diabetes arises from an imbalance between insulin sensitivity and secretion (42). That $\beta$ cell dysfunction plays a role in CKD is supported by several studies describing a prediabetic state in uremia that is characterized by both increased insulin resistance and defective insulin secretion (43-48).

Although urea and its breakdown product cyanate have emerged as important uremic toxins in recent years (49), their effects on islet function have not been addressed. Here, we provide evidence that defective insulin secretion associated with CKD is in large part mediated by urea. In adipose, endothelial, and renal cells, urea affects protein function by inducing ROS production $(14,50)$ and $O$-GlcNAcylation $(15,17)$. Accordingly, we found that urea adversely affects insulin secretion by increasing ROS and protein $O$-GlcNAcylation in islets. In addition to the direct effect of urea identified here, evidence in support of other uremic toxins disrupting $\beta$ cell function is emerging. Recently, uric acid was shown to affect insulin secretion by increasing oxidative stress in $\beta$ cells (51). In addition, the furan fatty acid metabolite 3-carboxy-4-methyl-5-propyl-2-furanpropanoic acid (CMPF), at concentrations found in CKD patients, impairs insulin secretion by inducing mitochondrial dysfunction and inhibition of insulin biosynthesis in $\beta$ cells (52). Furthermore, metabolic abnormalities associated with CKD, including hyperglycemia and dyslipidemia, as well as metabolic acidosis (45), low vitamin D levels (44), and hyperparathyroidism (48), may aggravate $\beta$ cell dysfunction in CKD. In our study, elevated fed FFA levels in CKD mice may have also contributed to the $\beta$ cell defect.

Circulating levels of urea in CKD can alter cellular functions via the breakdown product cyanate, which irreversibly forms carbamylated proteins by reacting with amino groups (18). The involvement of carbamylated proteins in mortality (53) and degenerative complications linked to $\mathrm{CKD}$, such as atherosclerosis and insulin resistance $(18,54)$, has been highlighted in several studies. We found that cyanate levels, within the range present in CKD mice and humans $(18,37)$, attenuate insulin secretion in normal mouse islets ex vivo and that this was prevented by the antioxidant NAC. However, in contrast to the effects of urea, cyanate did not increase protein $O$-GlcNAcylation, and DON did not restore insulin secretion in the presence of cyanate. This suggests that in this context, the deleterious effects of cyanate are not related to $O$-GlcNAcylation. We speculate that these may be due to protein carbamylation, although this remains to be directly tested. Nevertheless, the divergent mechanisms underlying $\beta$ cell dysfunction following exposure to urea and cyanate imply that the effect of urea to increase $O$-GlcNAcylation is not mediated by its degradation product. 
A
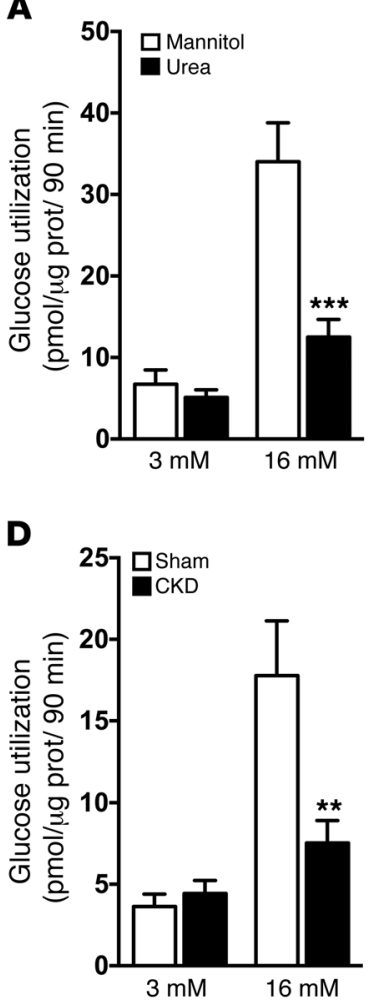

B

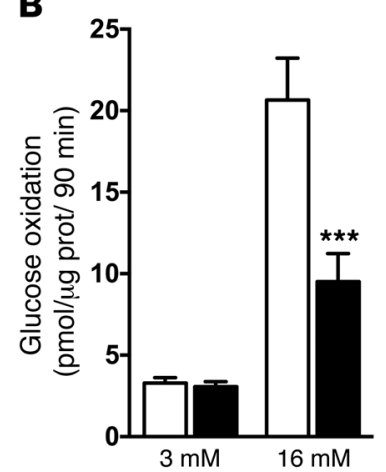

E

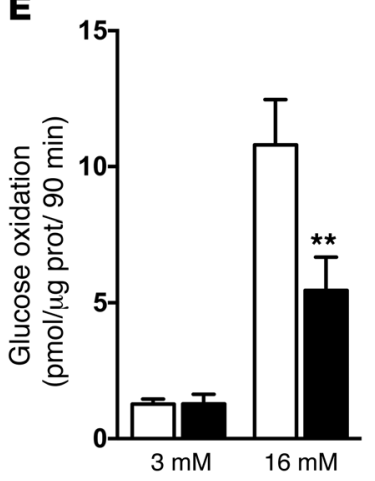

C

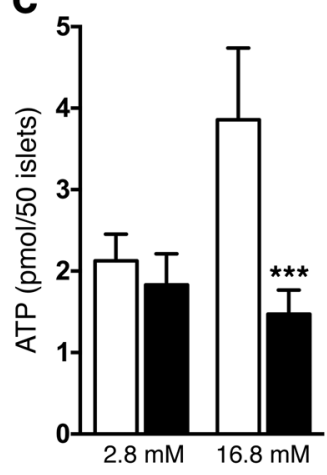

$\mathbf{F}$

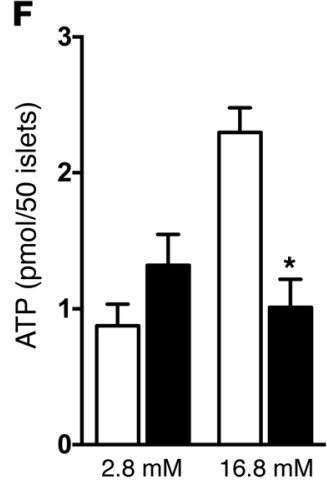

Figure 7. Normal mouse islets exposed to urea and islets from CKD mice have impaired glucose metabolism. Glucose utilization ( $\mathbf{A}$ and $\mathbf{D}$ ) and oxidation (B and $\mathbf{E}$ ) in islets incubated for 90 minutes in $\mathrm{KRBH}$ at 3 or $16 \mathrm{mmol} / \mathrm{l}(\mathrm{mM})$ glucose with $\mathrm{D}-\left[5-{ }^{3} \mathrm{H}\right]$ glucose and $\mathrm{D}-\left[\mathrm{U}-{ }^{14} \mathrm{C}\right]$ glucose in urea-treated and CKD islets $(n=4)$. (C and F) Total ATP content in islets incubated for 15 minutes in $\mathrm{KRBH}$ at 2.8 or $16.8 \mathrm{mmol} / \mathrm{l}$ glucose $(n=3-4)$. (G) Averaged data of exocytotic responses of single $\beta$ cells measured as increases in cell membrane capacitance by whole-cell patch clamp (arrow) performed after acute pretreatment with 2.8 or $16.7 \mathrm{mmol} / \mathrm{l}$ glucose (mean of 21 to 27 cells from 3 mice) after urea or mannitol treatment. Data represent the mean \pm SEM. ${ }^{*} P<0.05,{ }^{* *} P<0.01$, and ${ }^{* *} P<0.001$ versus control; 2 -way ANOVA with Bonferroni's post-hoc test for $\mathbf{G}$ and 1-way ANOVA with Bonferroni's post-hoc test for $\mathbf{A}-\mathbf{F}$.

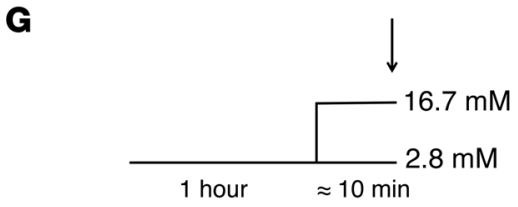

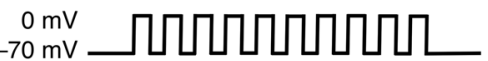

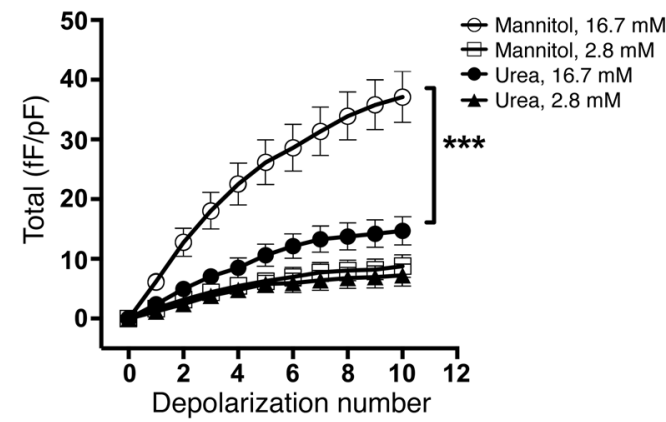

Increased levels of several plasmatic oxidative markers have been demonstrated in $\operatorname{CKD}(21,55,56)$, and CKD patients have defects in the antioxidant defense system (57). Moreover, several clinical studies suggest that antioxidant therapy in CKD patients may prevent the progression to end-stage renal disease and reduce CV mortality $(20,58)$. Oxidative stress also contributes to insulin resistance in CKD (15). In the $\beta$ cell, ROS derived from glucose metabolism, such as $\mathrm{H}_{2} \mathrm{O}_{2}$, act as metabolic signaling molecules for GSIS (22), but persistent oxidative stress is a cause of $\beta$ cell failure (23). The observed increase in oxidative stress, despite reduced glycolytic flux, suggests a nonmitochondrial source of ROS such as NADPH oxidase (59). In endothelial cells, NADPH oxidase activity increases upon urea exposure, suggesting a role for this enzyme in ROS production during uremia (17).

A link between increased protein $O$-GlcNAcylation and $\beta$ cell dysfunction in the context of uremia was demonstrated by the improvement in insulin secretion following exposure of CKD mice or urea-treated islets to GFAT inhibitors and GFAT knockdown in MIN6 cells. Protein O-GlcNAcylation is involved in both the physiological regulation of protein function and pathological phe- nomena (27). In islets, although $O$-GlcNAcylation of specific $\beta$ cell proteins such as PDX-1 and FOXO1 is essential for glucose regulation of gene expression (36) and insulin secretion (60), excessive protein $O$-GlcNAcylation reduces insulin secretion $(28-30,61)$ and increases $\beta$ cell apoptosis (62). Interestingly, protein $O$-GlcNAcylation in CKD mouse islets and in urea-treated islets was normalized by antioxidant treatment, implying that in the uremic context, ROS promote $O$-GlcNAcylation. Of note, defective insulin secretion in rat islets induced by overexpression of GFAT is mediated by elevated ROS (61), suggesting that $\beta$ cell dysfunction in CKD may involve a positive feedback loop that exacerbates the deregulation of ROS and the HBP. An alternative possibility to our conclusion that urea directly leads to an increase in ROS and $O$-GlcNAcylation of islet protein is that its effect in CKD and urea-fed mice is indirectly mediated by chronic hyperglycemia, a known cause of oxidative stress and increased flux through the HBP. However, this possibility is not supported by our observation that exposure of isolated islets to urea also induces protein $O$-GlcNAcylation, which can be prevented by NAC. In support of this, experimental evidence for ROS activation of the HBP in the 

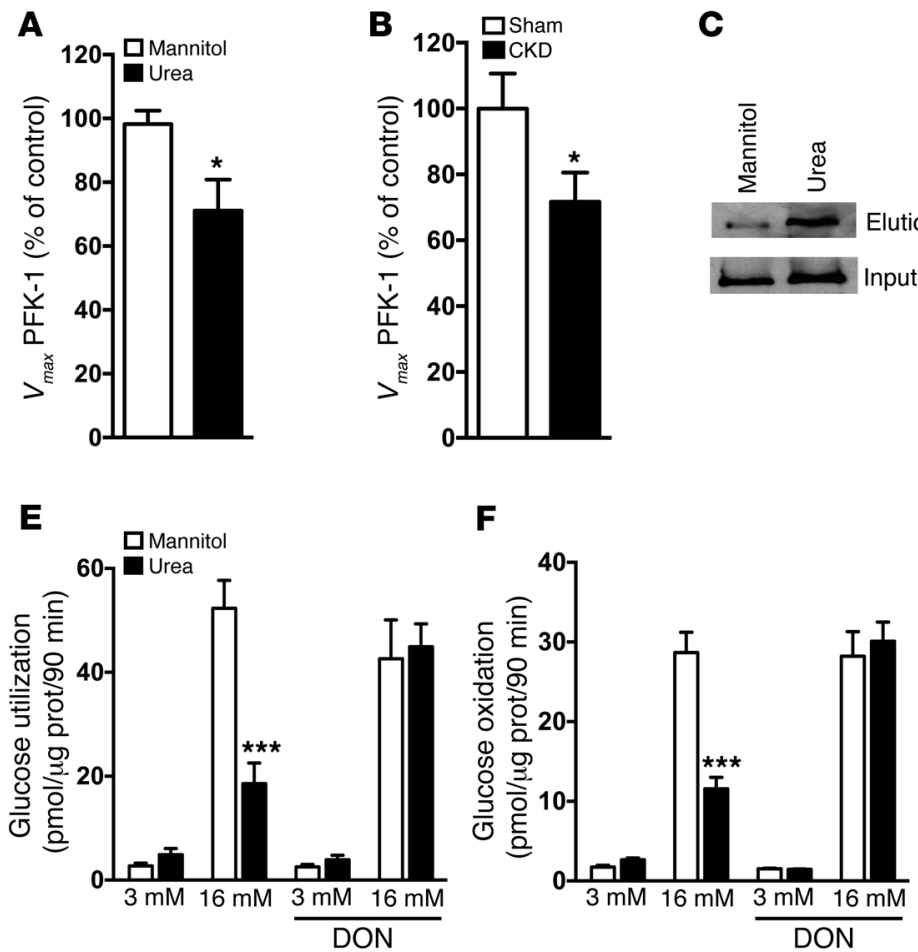

G

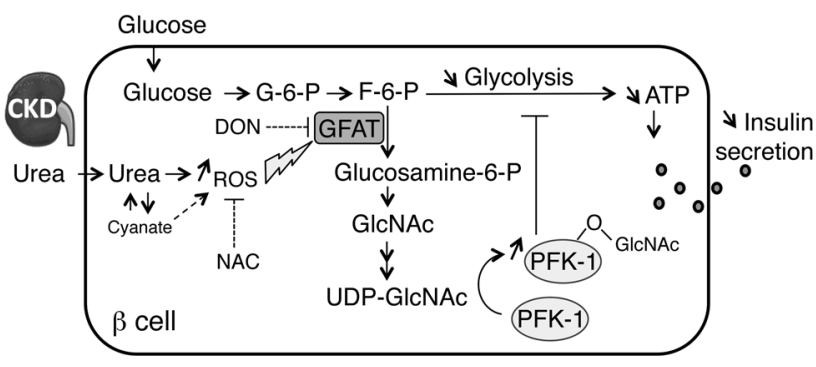

Figure 8. Inhibiting protein $\mathbf{O}$-GIcNAcylation in islets restores glucose metabolism and PFK-1 activity. $\mathrm{V}_{\text {max }}$ of PFK-1 in islets (A) after urea treatment $(n=3)$ and (B) in CKD islets $(n=4-5)$. (C) Representative Western blot (WB) showing PFK-1 O-GlcNAcylation after chemoenzymatic labeling of 0 -GlcNAc residues with UDP- $N$-azidoacetylgalactosamine and the enzyme galactose-1-phosphate uridylyltransferase, followed by reaction with an alkyne-biotin derivative, streptavidin pull-down, and elution of biotinylated proteins $(n=3)$. (D) $\mathrm{V}_{\text {max }}$ of PFK-1 in islets after urea treatment with or without DON $(n=4-5)$. Glucose utilization $(\mathbf{E})$ and oxidation $(\mathbf{F})$ in islets incubated for 90 minutes in $\mathrm{KRBH}$ at 3 or $16 \mathrm{mmol} / \mathrm{l}(\mathrm{mM})$ glucose with $\mathrm{D}-\left[5-{ }^{3} \mathrm{H}\right] \mathrm{glucose}$ and $\mathrm{D}$-[U- $\left.{ }^{-14} \mathrm{C}\right]$ glucose, respectively, in urea-treated islets with or without DON $(20 \mu \mathrm{mol} / \mathrm{I})(n=4)$. Data represent the mean \pm SEM. ${ }^{*} P<0.05$ and ${ }^{* * *} P<0.001$ versus control; 1-way ANOVA with Bonferroni's post-hoc test for $\mathbf{E}$ and $\mathbf{F}$ and Student's $t$ test for $\mathbf{A}$, B, and $\mathbf{D}$. (G) Schematic representation of the mechanisms of impaired insulin secretion in CKD.

absence of hyperglycemia was provided by d'Apolito et al. (15), who showed that urea can directly increase $O$-GlcNAcylation via ROS production in adipose tissue, and by Jones et al. (63), who demonstrated an increase in $O$-GlcNAcylation levels following short-term $\mathrm{H}_{2} \mathrm{O}_{2}$ exposure in isolated cardiac myocytes. Together, these studies and our findings support our conclusion that urea increases $O$-GlcNAcylation of islet proteins via ROS production.

Glucose utilization and oxidation were reduced in CKD mouse islets and in islets exposed to urea. This is consistent with the defective glucose metabolism observed in a rat CKD model (48) and with reduced first-phase, glucose-induced insulin secretion in CKD mouse islets. Both GK (64) and PFK-1 (65) are major rate-controlling enzymes of glycolysis, and $\beta$ cell-specific inactivation of either one impairs insulin secretion. Here, we found that PFK-1 activity was reduced in CKD islets as previously reported (48) and following exposure of islets to urea, while GK activity was not affected. PFK-1 activity is known to be inhibited by oxidative stress (66), lipid metabolites (67), and O-GlcNAcylation (38). Glycosylation of PFK-1 at Ser529 inhibits its activity (38). That urea-induced $O$-GlcNAcylation of PFK-1 may account for reduced glucose sensing in CKD is supported by the observed increase in $O$-GlcNAcylation of PFK- 1 after urea treatment of MIN6 cells and by the restoration of both PFK-1 activity and glucose utilization following the addition of DON to urea-treated islets. Reduced glucose metabolism compromises insulin secretion, however, decreased PFK-1 activity also leads to the diversion of glucose flux from the glycolytic pathway to the pentose phosphate (PPP) or glycogen synthesis pathway. Physiologically, the use of glucose-6-phosphate by these pathways is very limited in $\beta$ cells (68), yet under pathophysiological conditions, the PPP contributes to the inhibition of $\beta$ cell function (69) and, hence, could be a contributing factor to defective insulin secretion in CKD. Given that most enzymes in the glycolytic pathway are potentially $O$-GlcNAcylated $(38,70)$, it is possible that other enzymes are deregulated in addition to PFK-1. Further studies will be required to determine the contribution of these additional mechanisms to defective insulin secretion in CKD.

Stimulus-secretion coupling in the $\beta$ cell involves a glucose-dependent increase in the ATP/ADP ratio, which inhibits $\mathrm{K}_{\mathrm{ATP}}$ channels, induces membrane depolarization, and opens voltage-gated calcium channels. The subsequent rise in intracellular $\left[\mathrm{Ca}^{2+}\right]\left(\left[\mathrm{Ca}^{2+}\right]_{\mathrm{I}}\right)$ promotes insulin granule membrane fusion and exocytosis. In CKD rat islets, chronically elevated $\left[\mathrm{Ca}^{2+}\right]_{\mathrm{I}}$ alters insulin secretion (71) by reducing basal and glucose-induced ATP levels (48). In our models, resting ATP levels were unaffected, but the glucose-dependent rise in ATP was impaired, suggesting that the major defect lies at the level of glucose metabolism, probably as a consequence of reduced glycolysis. This was similarly reflected downstream, where an attenuated rise in $\left[\mathrm{Ca}^{2+}\right]_{\mathrm{I}}$ in response to glucose was observed in urea-treated islets (data not shown). It 
might seem counterintuitive that the insulin response to $\mathrm{KCl}$ was impaired in CKD islets, since $\mathrm{KCl}$ bypasses the glycolysis-regulated control of membrane potential and $\mathrm{Ca}^{2+}$ channels. However, work by Gembal et al. (72) and Sato et al. (73) has clearly shown that the magnitude of $\mathrm{KCl}$-induced secretory responses is regulated by glucose metabolism. Our own recent work (74) showed that the glucose-dependent amplification of insulin exocytosis occurs even at basal glucose concentrations and requires cytosolic redox signaling. Mechanistically, $\mathrm{KCl}$-induced insulin secretion may be reduced in two ways in the present study: 1) impaired glycolytic flux leading to reduced generation of coupling factors such as ATP can lead to reduced insulin granule priming; and 2) increased ROS may directly impair priming of insulin granules (74). In either case, this would be expected to result in fewer insulin granules available for $\mathrm{KCl}$-induced secretion.

Insulin content of CKD mouse islets was unchanged 3 weeks after surgery, but was lower after 6 weeks. This suggests that in this model, insulin secretion is already defective after 3 weeks, while insulin biosynthesis is not yet affected. To specifically explore this early secretory defect without the confounding effect of reduced insulin content, we focused on the 3-week time point for all subsequent experiments. We did not explore the mechanisms underlying the loss of insulin content at 6 weeks but can speculate that prolonged oxidative stress might eventually impair proinsulin gene expression and biosynthesis, as shown in other models (23).

Rodent models of CKD have provided important insights into the mechanism underlying perturbations in glucose homeostasis $(15,48,75,76)$. In support of our data, defective insulin secretion was described in CKD rat models $(48,75)$. In contrast to the modest decrease in insulin sensitivity observed in our CKD mouse model, d'Apolito et al. (15) reported insulin resistance in CKD mice. The differences between our results may be related to the genetic background of the mice (C57BL/6J vs. C57BL/6N used in this study) and/or the prevention of acidosis in our study. C57BL/6J mice carry a mutation in nicotinamide nucleotide transhydrogenase, a mitochondrial enzyme involved in NADPH production, and have reduced insulin secretion relative to that seen in the C57BL/6N strain, without changes in insulin sensitivity (77). Furthermore, overproduction of $\mathrm{H}_{2} \mathrm{O}_{2}$, indicative of alterations in NADPH-dependent oxidases, plays a critical role in urea-induced insulin resistance in adipocytes (15). Consequently, C57BL/6J mice may be vulnerable to urea-induced ROS generation and insulin resistance (15). Also, in our model, mice had access to drinking water containing $80 \mathrm{mmol} / \mathrm{l}$ sodium bicarbonate, preventing acidosis and hyperkalemia, which are known contributors to insulin resistance in CKD (78). Notwithstanding these differences, our model enabled us to study the impact of CKD on $\beta$ cell function in the absence of major changes in insulin sensitivity, although we cannot exclude the possibility that $\beta$ cell dysfunction itself might contribute to insulin resistance.

In summary, our study provided key information regarding the mechanisms of $\beta$ cell dysfunction in CKD using 3 complementary models with remarkably consistent functional defects. First, we uniquely demonstrated that urea, a major uremic toxin usually considered an innocent bystander, directly impairs insulin secretion. Second, we identified underlying mechanisms that involve ROS production; islet protein $O$-GlcNAcylation; decreased PFK-1 activity; PFK-1 O-GlcNAcylation; impaired glycolysis that results in reduced glucose oxidation; ATP production; exocytosis; and insulin secretion (Figure $8 \mathrm{G}$ ). Third, these deleterious effects of urea were also observed in human islets, indicating the relevance of the findings to human $\beta$ cells. Finally, the central role of ROS and $O$-GlcNAcylation in $\beta$ cell dysfunction suggests that clinical interventions such as antioxidant treatment might represent a therapeutic approach to reduce the metabolic complications associated with CKD.

\section{Methods}

\section{Reagents and solutions}

RPMI-1640, FBS, and DAPI were obtained from Invitrogen. DMEM was from MultiCell Technologies. Fatty acid-free BSA was from Equitech-Bio. Dextrose solution was from Baxter. Urea was from JT Baker. All other reagents were from Sigma-Aldrich unless otherwise noted.

\section{Animal models}

C57BL/6N male mice were purchased from Charles River Laboratories and housed in an air-conditioned room with a controlled environment of $21^{\circ} \mathrm{C} \pm 0.5^{\circ} \mathrm{C}$ and $60 \%-70 \%$ humidity, under a 12 -hour light/12-hour dark cycle, with free access to food (Teklad Global 18\% Protein Rodent Diet; Harlan Laboratories) and water. Mice were housed individually, and BW and food intake were determined biweekly. Moderate CKD was induced in 6-week-old mice by 5/6 nephrectomy with a 2-step surgical procedure, as previously described (31). NAC was dissolved in distilled water and administered daily by oral gavage at a dose of 200 $\mathrm{mg} / \mathrm{kg} /$ day for 3 weeks (79), beginning 2 days after the first surgery. Control animals received distilled water only. DON was dissolved in saline solution and administered i.p. 3 times per week at $0.5 \mathrm{mg} / \mathrm{kg}$. The control group was injected with the same volume of vehicle. The chronic urea model was initiated in 6-week-old mice. Mice were provided with drinking water containing $25 \mathrm{~g} / \mathrm{l}$ urea or urea-free water (control group) for 3 weeks.

\section{Tissue, blood collection, and biochemical measurements}

Blood samples obtained from the tail and collected in heparinized capillaries were used to measure fed and fasted blood glucose and insulin levels. Animals were fasted at $8 \mathrm{am}$, and the samples were collected at 8 am and 5 hours later. At the end of the experiment, mice were euthanized with ketamine $(70 \mathrm{mg} / \mathrm{kg})$ and xylazine $(4 \mathrm{mg} / \mathrm{kg})$, and blood was collected by left ventricular puncture using a syringe containing $0.2 \mu \mathrm{M}$ EDTA and centrifuged for 8 minutes at $10,000 \mathrm{~g}$ to separate the plasma. Blood was stored at $-80^{\circ} \mathrm{C}$. Urea was measured using a commercial colorimetric assay kit (BioVision). Creatinine was measured using a colorimetric method by the CHUM biochemistry core. Plasma FFA levels were measured using a kit from Wako Chemical. Insulin was measured by ELISA (Insulin Mouse Ultrasensitive Electroimmunoassay; ALPCO Diagnostics).

\section{Metabolic studies}

GTT. After a 5-hour fast, animals were injected i.p. with $1 \mathrm{~g} / \mathrm{kg}$ dextrose in sterile water. Blood glucose was measured prior to and 5, 10, $15,30,45,60,90$, and 120 minutes after injection. Blood glucose values were determined from a drop of blood sampled from the tail using an automatic glucose monitor (Accu-Check; Roche Applied Science). 
Plasma samples were collected at 0,5, 15, 30, and 60 minutes for insulin measurement. The AUC of blood glucose above basal levels was calculated using GraphPad Prism software.

ITT. After a 5-hour fast, animals were injected i.p. with $0.5 \mathrm{IU} / \mathrm{kg}$ recombinant human insulin (Actrapid; Novo Nordisk). Blood glucose was measured before and 15, 30, 40, 60, 90, and 120 minutes after injection. The glucose disappearance rate for the ITT (kITT) (percentage/minute) was calculated using the formula given by Lundbeck (33). $\mathrm{kITT}=0.693 \times 100 / t_{1 / 2}$, where $t_{1 / 2}$ was calculated from the slope of the plasma glucose concentration, considering an exponential decrement of glucose concentration during the 30 minutes after insulin administration.

HGCs. One-step HGCs were performed on conscious animals (fed ad libitum before the clamp) as described previously (80). At 80 minutes, an arginine bolus was injected ( $1 \mathrm{mmol} / \mathrm{kg}$; Sandoz Canada) to assess the maximal insulin response. Plasma samples were collected from the tail at $0,5,15,30,50,80,81$, and 90 minutes during the clamp, and the level of insulin was measured by ELISA. The insulin AUC in response to arginine was calculated using GraphPad Prism software. At the end of the clamp, the animals were sacrificed and the pancreas removed for morphological analyses. The M/I index of insulin sensitivity was calculated by dividing the average GIR during the second half of the glucose clamp (" $\mathrm{M}$ " is expressed in $\mu \mathrm{mol} / \mathrm{kg}$ / $\mathrm{min}$ ) by the average circulating insulin value ("I" is expressed in ng/ $\mathrm{ml}$ ) during the same time period.

\section{Islet isolation, cell culture, and urea and cyanate treatment}

Mouse islets were isolated by hand-picking after collagenase digestion of the pancreas and dextran density gradient centrifugation as described previously (81). Isolated islets from CKD or sham mice immediately underwent static incubations following isolation. For urea treatment, islets were isolated from 12 -week-old C57BL/6N male mice, and after overnight recovery in standard medium, islets were incubated for 24 hours in standard media containing 10-100 mmol/1 urea, 20-100 mmol/l mannitol (osmotic control), or 0.2-1 mmol/l sodium cyanate. Urea, mannitol, and cyanate were dissolved in sterile distilled water. Islets were treated with NAC (0.5 mmol/l), DON (20 $\mu \mathrm{mol} / \mathrm{l})$, or AZA $(5 \mu \mathrm{mol} / \mathrm{l})$ for 24 hours, with or without $20 \mathrm{mmol} / \mathrm{l}$ urea. NAC, DON, and AZA were dissolved in sterile ultrapure water.

The mouse insulin-secreting MIN6 cell line (passages 25-30; provided by Jun-ichi Miyazaki, Osaka University Graduate School of Medicine, Osaka, Japan) were maintained in DMEM containing 25 $\mathrm{mmol} / \mathrm{l}$ glucose, $4 \mathrm{mmol} / \mathrm{l} \mathrm{L}$-glutamine, and $44 \mathrm{mmol} / 1 \mathrm{NaHCO}_{3}$ and supplemented with $10 \% \mathrm{FBS}, 1 \mathrm{mmol} / 1$ sodium pyruvate, and $0.005 \%$ $\beta$-mercaptoethanol. Cells were electroporated with $350 \mathrm{pmol} / \mathrm{l}$ of either nontargeting (negative control) or siRNA against GFAT-1 (catalog sc-60682; Santa Cruz Biotechnology Inc.). Twenty-four hours after transfection, cells were cultured under the experimental conditions described in the Results. Gfat mRNA levels were measured by real-time RT-PCR (reverse transcription-PCR).

\section{Insulin secretion}

For static incubations of MIN6 cells, the cells were cultured at $2 \mathrm{mmol} / \mathrm{l}$ glucose in DMEM for 2 hours, then preincubated with Krebs-Ringer bicarbonate buffer plus HEPES (KRBH) containing 0.1\% (wt/vol) BSA at $2 \mathrm{mmol} / \mathrm{l}$ glucose for 1 hour. Cells were then incubated for 1 hour in the presence of $2 \mathrm{mmol} / \mathrm{l}$ or $16 \mathrm{mmol} / \mathrm{l}$ glucose. For islet static incu- bations, batches of 10 islets each were washed twice in KRB solution containing $0.1 \%$ (wt/vol) BSA and $2.8 \mathrm{mmol} / \mathrm{l}$ glucose for 20 minutes at $37^{\circ} \mathrm{C}$, then incubated for 1 hour in the presence of $2.8 \mathrm{mmol} / \mathrm{l} \mathrm{glu}-$ cose, or $16.8 \mathrm{mmol} / 1$ glucose or $2.8 \mathrm{mmol} / 1$ glucose plus $35 \mathrm{mmol} / \mathrm{l}$ $\mathrm{KCl}$. Each condition was run in triplicate. For perifusion experiments, batches of 120 islets each were placed in Swinnex chambers (EMD Millipore) and perifused for 40 minutes with KRB buffer containing $2.8 \mathrm{mmol} / \mathrm{l}$ glucose. The glucose concentration was increased to 16.7 $\mathrm{mmol} / \mathrm{l}$ at $t 0$ for a total of 40 minutes, then decreased to $2.8 \mathrm{mmol} / \mathrm{l}$. Samples were collected at 1-minute intervals for insulin determination. Intracellular insulin content was measured after acid-alcohol extraction. Insulin was measured by radioimmunoassay using a rat insulin RIA Kit (EMD Millipore) or an AlphaLISA Insulin Immunoassay Kit (PerkinElmer).

\section{Glucose metabolism and ATP content}

Glucose utilization and glucose oxidation. Groups of 20 isolated islets were incubated at $37^{\circ} \mathrm{C}$ for 90 minutes in $\mathrm{KRBH}, 0.1 \%$ BSA containing $0.5 \mu \mathrm{Ci}$ of $\mathrm{D}-\left[5-{ }^{3} \mathrm{H}\right]$ glucose $(16 \mathrm{Ci} / \mathrm{mmol})$, and $1 \mu \mathrm{Ci} / \mathrm{ml} \mathrm{D}-\left[\mathrm{U}-{ }^{14} \mathrm{C}\right]$ glucose $(250 \mathrm{mCi} / \mathrm{mmol})$ and 3 or $16 \mathrm{mmol} / \mathrm{l}$ glucose. Incubation was stopped by the addition of citrate buffer $(400 \mathrm{mmol} / \mathrm{l}, \mathrm{pH} 4.5)$ containing antimycin-A $(10 \mu \mathrm{mmol} / \mathrm{l})$, rotenone $(10 \mu \mathrm{mmol} / \mathrm{l})$, and potassium cyanide $(5 \mathrm{nmmol} / \mathrm{l})$. Glucose utilization was measured by the amount of ${ }^{3} \mathrm{H}_{2} \mathrm{O}$. Glucose oxidation was determined by the generation of ${ }^{14} \mathrm{CO}_{2}$ trapped by $5 \% \mathrm{KOH}$ after a 60 -minute incubation at room temperature. Results were normalized to the amount of protein in lysates, which was determined by using a BCA protein assay kit (Bio-Rad).

ATP content. ATP was extracted from islets after incubation at $37^{\circ} \mathrm{C}$ for 15 minutes in $\mathrm{KRBH}$ and $0.1 \%$ BSA containing 2.8 or 16.8 $\mathrm{mmol} / \mathrm{l}$ glucose and assayed using ATP bioluminescence assay according to the manufacturer's instructions (ATPlite Luminescence Assay; PerkinElmer).

\section{Single-cell measurement of $\beta$ cell exocytosis}

Prior to patch clamping, dissociated islet cells were preincubated in RPMI-1640 media with $2.8 \mathrm{mmol} / \mathrm{l}$ glucose for 1 hour. Media were then changed to a bath solution containing: $118 \mathrm{mmol} / \mathrm{l} \mathrm{NaCl}, 20$ $\mathrm{mmol} / \mathrm{l} \mathrm{TEA}, 5.6 \mathrm{mmol} / \mathrm{l} \mathrm{KCl}, 1.2 \mathrm{mmol} / \mathrm{l} \mathrm{MgCl}_{2} \cdot 6 \mathrm{H}_{2} \mathrm{O}, 2.6 \mathrm{mmol} / 1$ $\mathrm{CaCl}_{2}, 5 \mathrm{mmol} / \mathrm{l} \mathrm{HEPES}$, and either 2.8 or $16.7 \mathrm{mmol} / \mathrm{l}$ glucose in a $37^{\circ} \mathrm{C}$ chamber. After 10 minutes in the bath solution, whole-cell patch clamp measurement of exocytosis was performed (74). The intracellular solution contained: $125 \mathrm{mmol} / \mathrm{l} \mathrm{Cs}$-glutamate, $10 \mathrm{mmol} / \mathrm{l} \mathrm{CsCl}, 10$ $\mathrm{mmol} / \mathrm{l} \mathrm{NaCl}, 1 \mathrm{mmol} / 1 \mathrm{MgCl}_{2} \cdot 6 \mathrm{H}_{2} \mathrm{O}, 0.05 \mathrm{mmol} / \mathrm{l} \mathrm{EGTA}, 5 \mathrm{mmol} / 1$ HEPES, $0.1 \mathrm{mmol} / \mathrm{l} \mathrm{cAMP}$, and $3 \mathrm{mmol} / \mathrm{l} \mathrm{Mg}$ ATP (pH 7.15 with $\mathrm{CsOH}$ ). Capacitance responses in femtofarad ( $\mathrm{fF}$ ) were normalized to initial cell size in picofarad $(\mathrm{pF})$.

\section{Measurement of ROS in urea-treated islets}

The fluorescent probe 5-6-carboxy-2', $7^{\prime}$-dichlorodihydrofluorescein diacetate (carboxy- $\mathrm{H}_{2}$ DCFDA; Invitrogen, Thermo Fisher Scientific) was used to measure ROS accumulation in dissociated islets as previously described (82).

\section{PFK-1 and GK activity in islets}

Islets were lysed in lysis buffer (0.1 mol Tris, $\mathrm{pH} 8,5 \mathrm{mmol} / 1 \mathrm{MgCl}_{2}$, $2 \mathrm{mmol} / \mathrm{l}$ EGTA, $100 \mu \mathrm{mol} / \mathrm{l} \beta$-mercaptoethanol). PFK-1 $\mathrm{V}_{\max }$ was assayed as described (48) using $10 \mu \mathrm{g}$ islet lysate in $190 \mu \mathrm{l}$ buffer con- 
taining $0.1 \mathrm{~mol}$ Tris-HCl, $\mathrm{pH} 8,5 \mathrm{mmol} / \mathrm{l}$ EDTA, $\mathrm{pH} 8,0.02 \mathrm{mmol} / \mathrm{l}$ $\mathrm{MgCl}_{2}, 2 \mathrm{mmol} / 1$ fructose-6-phosphate, $0.2 \mathrm{mmol} / 1 \mathrm{NADH}, 10 \mathrm{U}$ aldolase, $10 \mathrm{U}$ triose phosphate isomerase, and $10 \mathrm{U} \alpha$-glycerophosphate dehydrogenase. Islets were then incubated for 10 minutes in the buffer at $37^{\circ} \mathrm{C}$, and the reaction was initiated by adding $2 \mathrm{mmol} / \mathrm{l}$ ATP to the buffer. Absorbance was recorded at $340 \mathrm{~nm}$ at room temperature every 15 seconds for 13 minutes using a spectrofluorimeter (FLUOstar; BMG LABTECH) PFK- $1 \mathrm{~V}_{\max }$ was estimated by the slope of disappearance of NADH. To measure $\mathrm{GK} \mathrm{V}_{\max }$, islets were lysed in buffer containing $50 \mathrm{mmol} / \mathrm{l}$ Tris, $5 \mathrm{mmol} / \mathrm{l} \mathrm{MgCl}_{2}, 100 \mathrm{mmol} / \mathrm{l} \mathrm{KCl}$, $1 \mathrm{mmol} / \mathrm{l} \mathrm{EDTA}$ and $4 \mathrm{mmol} / \mathrm{l}$ DTT. GK V $\mathrm{max}_{\text {mas }}$ measured using 10 $\mu \mathrm{g}$ islet lysate in $190 \mu \mathrm{l}$ reaction buffer containing $50 \mathrm{mmol} / \mathrm{l}$ Tris$\mathrm{HCl}, \mathrm{pH} 7.5,5 \mathrm{mmol} / 1 \mathrm{MgCl}_{2}, 1 \mathrm{mmol} / \mathrm{l} \mathrm{ATP}, 100 \mathrm{mmol} / \mathrm{l}$ glucose, $15 \mathrm{mmol} / \mathrm{l} \beta$-mercaptoethanol, $1 \mathrm{mmol} / \mathrm{l} \mathrm{NAD}^{+}$, and $1 \mathrm{U} / \mathrm{ml}$ glycerol6-phosphate dehydrogenase. Absorbance was recorded at $340 \mathrm{~nm}$ at $30^{\circ} \mathrm{C}$ every 30 seconds for 60 minutes. GK $\mathrm{V}_{\max }$ was estimated by the slope of appearance of NADH.

\section{PFK-1 0-GIcNAcylation}

Cell extracts were lysed in 1\% SDS, 50 mmol/l Tris- $\mathrm{HCl}, \mathrm{pH}$ 7.5, 100 $\mathrm{mmol} / \mathrm{l} \mathrm{NaCl}, 10 \mu \mathrm{mol} / \mathrm{l}$ PUGNAc, $1 \mu \mathrm{g} / \mathrm{ml}$ leupeptin, and $10 \mu \mathrm{g} / \mathrm{ml}$ aprotinin. Using $200 \mu \mathrm{g}$ proteins, chemoenzymatic labeling and biotinylation were carried out as described $(38,83)$. Briefly, the cell lysate was labeled according to the Click-iT $O$-GlcNAc Enzymatic Labeling System protocol (Invitrogen, Thermo Fisher Scientific) and conjugated with an alkyne-biotin compound according to the Click-iT Protein Analysis Detection Kit protocol (Invitrogen, Thermo Fisher Scientific). Negative control experiments were carried out in parallel in the absence of the labeling enzyme GalT. Biotinylated lysates were precipitated in methanol/chloroform according to the manufacturer's instructions. Protein pellets were solubilized with $1 \%$ SDS and $50 \mathrm{mmol} / \mathrm{l}$ Tris- $\mathrm{HCl}, \mathrm{pH}$ 8.0, and neutralized with an equal volume of the neutralization buffer (6\%NP-40, $\left.100 \mathrm{mmol} / 1 \mathrm{Na}_{2} \mathrm{HPO}_{4}, 150 \mathrm{mmol} / \mathrm{l} \mathrm{NaCl}\right)$. Lysates were then incubated with streptavidin resin (Pierce, Thermo Fisher Scientific) at a ratio of $30 \mu \mathrm{l}$ resin to $100 \mu \mathrm{g}$ proteins, with endto-end rotation at $4^{\circ} \mathrm{C}$ overnight. The following day, all samples were centrifuged at 5,000 $g$ for 3 minutes, and the supernatant (input) was collected and assessed by Western blot analysis. Resins were washed 5 times with $1 \mathrm{ml} \mathrm{low}$-salt buffer $\left(100 \mathrm{mmol} / \mathrm{l} \mathrm{Na}_{2} \mathrm{HPO}_{4}, 150 \mathrm{mmol} / \mathrm{l}\right.$ $\mathrm{NaCl}, 0.1 \%$ SDS, $1 \%$ Triton $\mathrm{X}-100,0.5 \%$ sodium deoxycholate) and 5 times with $1 \mathrm{ml}$ high-salt buffer $\left(100 \mathrm{mmol} / \mathrm{l} \mathrm{Na}{ }_{2} \mathrm{HPO}_{4}, 500 \mathrm{mmol} / \mathrm{l}\right.$ $\mathrm{NaCl}, 0.2 \%$ Triton $\mathrm{X}-100)$. After washing, biotinylated proteins were eluted by boiling the resin in $50 \mu \mathrm{l}$ elution buffer $(50 \mathrm{mmol} / \mathrm{l}$ Tris- $\mathrm{HCl}$, $\mathrm{pH}$ 6.8, 2.5\% SDS, $100 \mathrm{mmol} / \mathrm{l} \mathrm{DTT,} 10 \%$ glycerol and $20 \mathrm{mmol} / \mathrm{l}$ biotin) for 10 minutes at $90^{\circ} \mathrm{C}$. Samples were centrifuged at 2,000 $\mathrm{g}$ for 1 minute. Supernatants were collected for Western blot analysis.

\section{Immunostaining of pancreatic sections}

Pancreata were trimmed of fat, weighed, and fixed in $4 \%$ paraformaldehyde for 24 hours, followed by embedment in paraffin blocks. Paraffin sections were rehydrated, and antigen retrieval was performed using sodium citrate buffer. Abs and dilutions are listed in Supplemental Table 6. Images were taken with a fluorescence microscope (Zeiss). To measure $\beta$ cell mass, pancreatic sections were cut at $5-\mu \mathrm{m}$ thickness and collected at 50- $\mu \mathrm{m}$ intervals. At least 6 slides from each pancreas were processed for $\beta$ cell mass measurement. $\beta$ cell mass was analyzed after insulin immunostaining and hematoxylin coun- terstaining as described previously (84). The slides were scanned using a Super CoolScan 9000 scanner (Nikon), and images were analyzed using Image J software (NIH) to assess $\beta$ cell and whole pancreas areas. The fractional $\beta$ cell area was multiplied by the pancreas weight to obtain $\beta$ cell mass.

\section{Immunoblotting}

Islet proteins were extracted using lysis buffer $(20 \mathrm{mmol} / \mathrm{l}$ Tris- $\mathrm{HCl}$, pH 7.2, containing $150 \mathrm{mmol} / 1 \mathrm{NaCl}, 1 \mathrm{mmol} / \mathrm{l} \mathrm{EDTA}, 1 \mathrm{mmol} / \mathrm{l} \mathrm{EGTA}$, $1 \%$ (v/v) Triton X-100, 0.1\% SDS, $1 \mu \mathrm{g} / \mathrm{ml}$ leupeptin, $10 \mu \mathrm{g} / \mathrm{ml}$ aprotinin and $20 \mu \mathrm{mol} / \mathrm{l}$ PUGNAc), followed by sonication. Insoluble material was removed by centrifugation at $10,000 \mathrm{~g}$ at $4{ }^{\circ} \mathrm{C}$ for 10 minutes. Protein extracts $(15 \mu \mathrm{g})$ were separated on $10 \%$ (wt/vol) SDS-PAGE, blotted to nitrocellulose membranes (Whatman). Membranes were blocked with $5 \%(\mathrm{w} / \mathrm{v})$ BSA in Tris-buffered saline, $\mathrm{pH} 7.5$, with $0.1 \%$ (v/v) Tween (TBS-T) for 2 hours at room temperature and incubated overnight at $4^{\circ} \mathrm{C}$ with the primary Abs listed in Supplemental Table 6 . Blots were washed with TBS-T and exposed to secondary Abs for 1 hour at room temperature. Membranes were washed again and developed by enhanced chemiluminescence using a standard kit (SuperSignal West Pico Chemiluminescent Substrate; Life Technologies, Thermo Fisher Scientific). Signals were detected using an HRP-labeled IgG (Bio-Rad) and enhanced chemiluminescence (PerkinElmer) on Kodak BioMax XAR films (Kodak). The bands were quantified by densitometry and ImageJ. For the normalization of protein levels, membranes were incubated with anti-tubulin Ab. Results are expressed as a fold increase over control values.

\section{Human isolated islets and pancreatic sections}

Isolated islets from nondiabetic human cadaveric donors were provided by the Alberta Diabetes Institute Islet Core at the University of Alberta and by the Integrated Islet Distribution Program sponsored by the National Institute of Diabetes and Digestive and Kidney Diseases (NIDDK). Characteristics of the donors are summarized in Supplemental Table 5.

Human pancreatic sections were prepared from autopsy samples from the Department of Pathology of the CHUM. CKD patients were selected on the basis of the absence of diabetes in their clinical history and an estimated glomerular filtration (eGFR) rate (by the CKD-EPI formula) under $60 \mathrm{ml} / \mathrm{min} / 1.73 \mathrm{~m}^{2}$. Age- and sex-matched controls were selected on the basis of a normal eGFR rate. Characteristics of the donors are summarized in Supplemental Table 2.

\section{Statistics}

Data are expressed as the mean \pm SEM. All data were analyzed using GraphPad Prism (GraphPad Software 6). Multiple comparisons were performed using 1-way ANOVA followed, when appropriate, by Bonferroni's post-hoc tests for 2-by-2 comparisons. Results of GTT, ITT, clamps, and BW tests were compared by 2-way ANOVA (time, treatment). Simple comparisons were performed using a 2-tailed Student's $t$ test. A $P$ value of less than 0.05 was considered statistically significant.

\section{Study approval}

All procedures using animals were approved by the Institutional Committee for the Protection of Animals at the CHUM (protocol CM13041VP). The use of isolated human islets and human pancreatic sections was approved by the Institutional Ethics Committee of 
the CHUM (protocols ND-05-035 and 16-048, respectively). Written consent for research was obtained from all donors.

\section{Author contributions}

LK conceived and performed the study, researched data, analyzed the results, and wrote the manuscript. EN performed the study, researched data, analyzed the results, and reviewed the manuscript. KV, JEMF, XQD, BNN, DT, CA, and VSM researched data and analyzed the results. JG and PEM analyzed the results and reviewed the manuscript. VP conceived the study, analyzed the results, and wrote the manuscript. LK and VP are the guarantors of this work and, as such, take full responsibility for it.

\section{Acknowledgments}

This study was supported by the US NIH (R01DK58096, to V.P.); the Canadian Institutes of Health Research (MOP 77686, to V.P.); and the Quebec Research Network in Cardiometabolic Health, Diabetes and Obesity. VP holds the Canada Research Chair in Dia- betes and Pancreatic Beta-Cell Function. PEM holds the Canada Research Chair in Islet Biology. LK was supported by postdoctoral fellowships from the INSERM - Fond de Recherches Santé Québec (FRQS); the CRCHUM; and Hospices Civils de Lyon. EN was supported by studentships from the University of Montréal and the Montreal Diabetes Research Center. KV, VSM, and CA were supported by postdoctoral fellowships from the FRQS, CRCHUM, and the Canadian Diabetes Association, respectively. We thank G. Fergusson and M. Éthier of the Rodent Metabolic Phenotyping core facility of the CRCHUM for metabolic studies in mice; M. Guévremont, J. Morin, and the Cellular Physiology Service core of the CRCHUM for quantification of $\beta$ cell mass and $\alpha$ LISA assay; $\mathrm{C}$. Tremblay (CRCHUM) for valuable technical assistance; E. Joly for technical advice; and M. Ferdaoussi for fruitful discussions.

Address correspondence to: Vincent Poitout, CRCHUM, 900 Saint-Denis Street, Montreal, Quebec, H2X OA9, Canada. Phone: 514.890.8044; E-mail: vincent.poitout@umontreal.ca.
1. Eldin WS, Ragheb A, Klassen J, Shoker A. Evidence for increased risk of prediabetes in the uremic patient. Nephron Clin Pract. 2008;108(1):c47-c55.

2. Lorenzo C, Nath SD, Hanley AJ, Abboud HE, Gelfond JA, Haffner SM. Risk of type 2 diabetes among individuals with high and low glomerular filtration rates. Diabetologia. 2009;52(7):1290-1297.

3. Sahakyan K, Lee KE, Shankar A, Klein R. Serum cystatin $\mathrm{C}$ and the incidence of type 2 diabetes mellitus. Diabetologia. 2011;54(6):1335-1340.

4. Mak RH. Insulin and its role in chronic kidney disease. Pediatr Nephrol. 2008;23(3):355-362.

5. Menon V, et al. Glycosylated hemoglobin and mortality in patients with nondiabetic chronic kidney disease. JAm Soc Nephrol. 2005;16(11):3411-3417.

6. Trivin C, et al. Glycated hemoglobin level and mortality in a nondiabetic population with CKD. Clin JAm Soc Nephrol. 2015;10(6):957-964.

7. Koppe L, et al. Insulin resistance in chronic kidney disease: new lessons from experimental models. Nephrol Dial Transplant. 2014;29(9):1666-1674.

8. Cohen G, et al. Review on uraemic toxins III: recommendations for handling uraemic retention solutes in vitro--towards a standardized approach for research on uraemia. Nephrol Dial Transplant. 2007;22(12):3381-3390.

9. Duranton F, et al. Normal and pathologic concentrations of uremic toxins. J Am Soc Nephrol. 2012;23(7):1258-1270.

10. Johnson WJ, Hagge WW, Wagoner RD, Dinapoli RP, Rosevear JW. Effects of urea loading in patients with far-advanced renal failure. Mayo Clin Proc. 1972;47(1):21-29.

11. Eknoyan G, et al. Effect of dialysis dose and membrane flux in maintenance hemodialysis. N Engl J Med. 2002;347(25):2010-2019.

12. FHN Trial Group, et al. In-center hemodialysis six times per week versus three times per week. N Engl J Med. 2010;363(24):2287-2300.

13. Maduell F, et al. High-efficiency postdilution online hemodiafiltration reduces all-cause mor- tality in hemodialysis patients. J Am Soc Nephrol. 2013;24(3):487-497.

14. Zhang Z, Yang XY, Cohen DM. Urea-associated oxidative stress and Gadd153/CHOP induction. Am J Physiol. 1999;276(5 Pt 2):F786-F793.

15. D’Apolito M, et al. Urea-induced ROS generation causes insulin resistance in mice with chronic renal failure. JClin Invest. 2010;120(1):203-213.

16. Vaziri ND, Yuan J, Norris K. Role of urea in intestinal barrier dysfunction and disruption of epithelial tight junction in chronic kidney disease. Am J Nephrol. 2013;37(1):1-6.

17. D'Apolito M, et al. Urea-induced ROS cause endothelial dysfunction in chronic renal failure. Atherosclerosis. 2015;239(2):393-400.

18. Wang $\mathrm{Z}$, et al. Protein carbamylation links inflammation, smoking, uremia and atherogenesis. Nat Med. 2007;13(10):1176-1184.

19. De Vos A, et al. Human and rat beta cells differ in glucose transporter but not in glucokinase gene expression. JClin Invest. 1995;96(5):2489-2495.

20. Tepel M, van der Giet M, Statz M, Jankowski J, Zidek W. The antioxidant acetylcysteine reduces cardiovascular events in patients with end-stage renal failure: a randomized, controlled trial. Circulation. 2003;107(7):992-995.

21. Dounousi E, et al. Oxidative stress is progressively enhanced with advancing stages of CKD. Am J Kidney Dis. 2006;48(5):752-760.

22. Pi J, et al. Reactive oxygen species as a signal in glucose-stimulated insulin secretion. Diabetes. 2007;56(7):1783-1791.

23. Poitout V, Robertson RP. Glucolipotoxicity: fuel excess and beta-cell dysfunction. Endocr Rev. 2008;29(3):351-366.

24. Lenzen S, Drinkgern J, Tiedge M. Low antioxidant enzyme gene expression in pancreatic islets compared with various other mouse tissues. Free Radic Biol Med. 1996;20(3):463-466.

25. Brownlee M. Biochemistry and molecular cell biology of diabetic complications. Nature. 2001;414(6865):813-820.

26. Lima VV, Spitler K, Choi H, Webb RC, Tostes RC. $\mathrm{O}-$ GlcNAcylation and oxidation of proteins: is signalling in the cardiovascular system becoming sweeter?. Clin Sci. 2012;123(8):473-486.

27. Bond MR, Hanover JA. O-GlcNAc cycling: a link between metabolism and chronic disease. Annu Rev Nutr. 2013;33:205-229.

28. Akimoto Y, et al. Elevation of the post-translational modification of proteins by O-linked $\mathrm{N}$-acetylglucosamine leads to deterioration of the glucose-stimulated insulin secretion in the pancreas of diabetic Goto-Kakizaki rats. Glycobiology. 2007;17(2):127-140.

29. Konrad RJ, Kudlow JE. The role of O-linked protein glycosylation in beta-cell dysfunction. Int J Mol Med.2002;10(5):535-539.

30. Cooksey RC, Pusuluri S, Hazel M, McClain DA. Hexosamines regulate sensitivity of glucose-stimulated insulin secretion in beta-cells. Am J Physiol Endocrinol Metab. 2006;290(2):E334-E340.

31. Koppe L, et al. p-Cresyl sulfate promotes insulin resistance associated with CKD. JAm Soc Nephrol. 2013;24(1):88-99.

32. Covic AM, Schelling JR, Constantiner M, Iyengar SK, Sedor JR. Serum C-peptide concentrations poorly phenotype type 2 diabetic end-stage renal disease patients. Kidney Int. 2000;58(4):1742-1750.

33. Lundbaek K. Intravenous glucose tolerance as a tool in definition and diagnosis of diabetes mellitus. Br Med J. 1962;1(5291):1507-1513.

34. Kikuchi A, et al. Systemic increase of oxidative nucleic acid damage in Parkinson's disease and multiple system atrophy. Neurobiol Dis. 2002;9(2):244-248.

35. Buchwalow I, et al. L-arginine-NO-cGMP signalling pathway in pancreatitis. Sci Rep. 2013;3:1899.

36. Kebede M, et al. Glucose activates free fatty acid receptor 1 gene transcription via phosphatidylinositol-3-kinase-dependent O-GlcNAcylation of pancreas-duodenum homeobox-1. Proc Natl Acad Sci USA. 2012;109(7):2376-2381.

37. El-Gamal D, et al. The urea decomposition product cyanate promotes endothelial dysfunction. Kidney Int. 2014;86(5):923-931.

38. Yi W, et al. Phosphofructokinase 1 glycosylation 
regulates cell growth and metabolism. Science. 2012;337(6097):975-980.

39. Katz AI, Rubenstein AH. Metabolism of proinsulin, insulin, and C-peptide in the rat. J Clin Invest. 1973;52(5):1113-1121.

40. Mondon CE, Dolkas CB, Reaven GM. Effect of acute uremia on insulin removal by the isolated perfused rat liver and muscle. Metab Clin Exp. 1978;27(2):133-142.

41. DeFronzo RA, Tobin JD, Rowe JW, Andres R. Glucose intolerance in uremia. Quantification of pancreatic beta cell sensitivity to glucose and tissue sensitivity to insulin. JClin Invest. 1978;62(2):425-435.

42. Bergman RN. Minimal model: perspective from 2005. Horm Res. 2005;64(Suppl 3):8-15.

43. Alvestrand A, Mujagic M, Wajngot A, Efendic S. Glucose intolerance in uremic patients: the relative contributions of impaired beta-cell function and insulin resistance. Clin Nephrol. 1989;31(4):175-183.

44. Mak RH.1,25-Dihydroxyvitamin D3 corrects insulin and lipid abnormalities in uremia. Kidney Int. 1998;53(5):1353-1357.

45. Mak RH. Effect of metabolic acidosis on insulin action and secretion in uremia. Kidney Int. 1998;54(2):603-607.

46. Idorn T, Knop FK, Jørgensen M, Holst JJ, Hornum M, Feldt-Rasmussen B. Gastrointestinal factors contribute to glucometabolic disturbances in nondiabetic patients with end-stage renal disease. Kidney Int. 2013;83(5):915-923.

47. Allegra V, Mengozzi G, Martimbianco L, Vasile A. Glucose-induced insulin secretion in uremia: effects of aminophylline infusion and glucose loads. Kidney Int . 1990;38(6):1146-1150.

48. Fadda GZ, Hajjar SM, Perna AF, Zhou XJ, Lipson LG, Massry SG. On the mechanism of impaired insulin secretion in chronic renal failure. JClin Invest. 1991;87(1):255-261.

49. Duranton F, Depner TA, Argilés À. The saga of two centuries of urea: Nontoxic toxin or vice versa?. Semin Nephrol. 2014;34(2):87-96.

50. Zhang Z, Dmitrieva NI, Park JH, Levine RL, Burg $\mathrm{MB}$. High urea and $\mathrm{NaCl}$ carbonylate proteins in renal cells in culture and in vivo, and high urea causes 8-oxoguanine lesions in their DNA. Proc Natl Acad Sci U S A. 2004;101(25):9491-9496.

51. Jia $L$, et al. Hyperuricemia causes pancreatic $\beta$-cell death and dysfunction through NF- $\mathrm{KB}$ signaling pathway. PLOS ONE. 2013;8(10):e78284.

52. Prentice KJ, et al. The furan fatty acid metabolite CMPF is elevated in diabetes and induces $\beta$ cell dysfunction. Cell Metab. 2014;19(4):653-666.

53. Koeth RA, Kalantar-Zadeh K, Wang Z, Fu X, Tang WH, Hazen SL. Protein carbamylation predicts mortality in ESRD. JAm Soc Nephrol. 2013;24(5):853-861.

54. Kraus LM, Traxinger R, Kraus AP. Uremia and insulin resistance: $\mathrm{N}$-carbamoyl-asparagine decreases insulin-sensitive glucose uptake in rat adipocytes. Kidney Int. 2004;65(3):881-887.
55. Oberg BP, et al. Increased prevalence of oxidant stress and inflammation in patients with moderate to severe chronic kidney disease. Kidney Int. 2004;65(3):1009-1016.

56. Ruiz S, Pergola PE, Zager RA, Vaziri ND. Targeting the transcription factor Nrf2 to ameliorate oxidative stress and inflammation in chronic kidney disease. Kidney Int. 2013;83(6):1029-1041.

57. Del Vecchio L, Locatelli F, Carini M. What we know about oxidative stress in patients with chronic kidney disease on dialysis--clinical effects, potential treatment, and prevention. Semin Dial. 2011;24(1):56-64.

58. Jun M, et al. Antioxidants for chronic kidney disease. Cochrane Database Syst Rev. 2012;10:CD008176.

59. Guichard C, Moreau R, Pessayre D, Epperson TK, Krause KH. NOX family NADPH oxidases in liver and in pancreatic islets: a role in the metabolic syndrome and diabetes?. Biochem Soc Trans. 2008;36(Pt 5):920-929.

60. Gao Y, Miyazaki J, Hart GW. The transcription factor PDX-1 is post-translationally modified by O-linked $\mathrm{N}$-acetylglucosamine and this modification is correlated with its DNA binding activity and insulin secretion in min 6 beta-cells. Arch Biochem Biophys. 2003;415(2):155-163.

61. Kaneto H, et al. Activation of the hexosamine pathway leads to deterioration of pancreatic betacell function through the induction of oxidative stress. J Biol Chem. 2001;276(33):31099-31104.

62. Fardini $\mathrm{Y}$, et al. O-GlcNAcylation of FoxO1 in pancreatic $\beta$ cells promotes Akt inhibition through an IGFBP1-mediated autocrine mechanism. FASEB J. 2014;28(2):1010-1021.

63. Jones SP, et al. Cardioprotection by $\mathrm{N}$-acetylglucosamine linkage to cellular proteins. Circulation. 2008;117(9):1172-1182.

64. Terauchi Y, et al. Pancreatic beta-cell-specific targeted disruption of glucokinase gene. Diabetes mellitus due to defective insulin secretion to glucose. J Biol Chem. 1995;270(51):30253-30256.

65. Richard AM, et al. Tissue-dependent loss of phosphofructokinase-M in mice with interrupted activity of the distal promoter: impairment in insulin secretion. Am J Physiol Endocrinol Metab. 2007;293(3):E794-E801.

66. Tsuura Y, Ishida H, Shinomura T, Nishimura M, Seino Y. Endogenous nitric oxide inhibits glucose-induced insulin secretion by suppression of phosphofructokinase activity in pancreatic islets. Biochem Biophys Res Commun. 1998;252(1):34-38

67. Jenkins CM, Yang J, Sims HF, Gross RW. Reversible high affinity inhibition of phosphofructokinase- 1 by acyl-CoA: a mechanism integrating glycolytic flux with lipid metabolism. J Biol Chem. 2011;286(14):11937-11950.

68. Schuit F, et al. Metabolic fate of glucose in purified islet cells. Glucose-regulated anaplerosis in beta cells. J Biol Chem. 1997;272(30):18572-18579.

69. Goehring I, et al. Identification of an intracellular metabolic signature impairing beta cell function in the rat beta cell line INS-1E and human islets. Diabetologia. 2011;54(10):2584-2594.

70. Rao X, et al. O-GlcNAcylation of G6PD promotes the pentose phosphate pathway and tumor growth. Nat Commun. 2015;6:8468.

71. Hajjar SM, Fadda GZ, Thanakitcharu P, Smogorzewski M, Massry SG. Reduced activity of $\mathrm{Na}(+)-\mathrm{K}+$ ATPase of pancreatic islets in chronic renal failure: role of secondary hyperparathyroidism. J Am Soc Nephrol. 1992;2(8):1355-1359.

72. Gembal M, Gilon P, Henquin JC. Evidence that glucose can control insulin release independently from its action on ATP-sensitive $\mathrm{K}+$ channels in mouse B cells. J Clin Invest. 1992;89(4):1288-1295.

73. Sato Y, Aizawa T, Komatsu M, Okada N, Yamada T. Dual functional role of membrane depolarization/Ca2+ influx in rat pancreatic B-cell. Diabetes. 1992;41(4):438-443.

74. Ferdaoussi M, et al. Isocitrate-to-SENP1 signaling amplifies insulin secretion and rescues dysfunctional $\beta$ cells. JClin Invest. 2015;125(10):3847-3860.

75. Nakamura Y, Yoshida T, Kajiyama S, Kitagawa Y, Kanatsuna T, Kondo M. Insulin release from column-perifused isolated islets of uremic rats. Nephron. 1985;40(4):467-469.

76. Pokrywczynska M, et al. Impact of fructose diet and renal failure on the function of pancreatic islets. Pancreas. 2014;43(5):801-808.

77. Fergusson G, et al. Defective insulin secretory response to intravenous glucose in $\mathrm{C} 57 \mathrm{Bl} / 6 \mathrm{~J}$ compared to $\mathrm{C} 57 \mathrm{Bl} / 6 \mathrm{~N}$ mice. Mol Metab. 2014;3(9):848-854.

78. Bailey JL, Zheng B, Hu Z, Price SR, Mitch WE. Chronic kidney disease causes defects in signaling through the insulin receptor substrate/phosphatidylinositol 3-kinase/Akt pathway: implications for muscle atrophy. J Am Soc Nephrol. 2006;17(5):1388-1394.

79. Ivanovski $\mathrm{O}$, et al. The antioxidant $\mathrm{N}$-acetylcysteine prevents accelerated atherosclerosis in uremic apolipoprotein $\mathrm{E}$ knockout mice. Kidney Int. 2005;67(6):2288-2294.

80. Peyot ML, et al. Adipose triglyceride lipase is implicated in fuel- and non-fuel-stimulated insulin secretion. J Biol Chem. 2009;284(25):16848-16859.

81. Alquier T, et al. Deletion of GPR40 impairs glucose-induced insulin secretion in vivo in mice without affecting intracellular fuel metabolism in islets. Diabetes. 2009;58(11):2607-2615.

82. Moore PC, Ugas MA, Hagman DK, Parazzoli SD, Poitout V. Evidence against the involvement of oxidative stress in fatty acid inhibition of insulin secretion. Diabetes. 2004;53(10):2610-2616.

83. Tai HC, Khidekel N, Ficarro SB, Peters EC, Hsieh-Wilson LC. Parallel identification of O-GlcNAc-modified proteins from cell lysates. JAm Chem Soc. 2004;126(34):10500-10501.

84. Fontés G, et al. Glucolipotoxicity age-dependently impairs beta cell function in rats despite a marked increase in beta cell mass. Diabetologia. 2010;53(11):2369-2379. 